\title{
Modern Toplumun Oluşum Sürecinde Politika, Toplum ve İletişim: Modern İngiltere'nin İlk Dönemi
}

\section{Politics, Society and Communication in the Constitution of Modern Society: Early Modern England}

\author{
Devrim ÖZKAN* \\ İzmir Katip Çelebi Üniversitesi
}

\author{
Halil Saim PARLADIR ${ }^{* *}$ \\ İzmir Katip Çelebi Üniversitesi
}

Özet

\begin{abstract}
Modern İngiltere'nin ilk dönemi, on altıncı yüzyllın başı ile on sekizinci yüzylın ortası arasında geçen iki yüz elli ylllık bir dönemi kapsar. Bu iki yüzyıl boyunca, günümüz modern toplumlarının yapısal nitelikleri oluşmuştur. Bu dönemde, İngiltere'deki politik ve ekonomik sahada gerçekleşen değişim ve dönüşümler devasa ölçektedir. Tüm toplumsal yapı ve kurumlar kültürel, ekonomik ve politik işleyişleri bakımından yapısal dönüşüm geçirmiştir. Ayrıca, bu dönemde, uluslararası sistemin ekonomik ve politik açıdan merkezi bir biçimde tesis edilmesinin alt yapısı hazırlanmış̧ır. Günümüz modern toplumlarının en önemli özelliklerinden biri, parçaları arasındaki iletişim ve etkileşimin hızı, dönüştürücü niteliği, sürekliliği ve kapsamlarının genişliğidir. Bunu sağlayan toplumsal yapının ve gelişmelerin oluşumu modern İngiltere'nin ilk döneminde gerçekleşmiştir. Bu nedenle günümüz enformasyon ve iletişim çağının temel yapı taşları modern İngiltere'nin ilk döneminin analiziyle tespit edilebilir.

Anahtar Kelimeler: Modern toplum, İletişim, Politika, İngiltere, Din.
\end{abstract}

\begin{abstract}
The inception of Modern England comprises a hundred and fifty years between sixteenth and mid eighteenth centuries. The structural qualities of modern societies of this day occur in this era. The political and economic changes and transformations that England experienced in this period of time are in enormous scale. In this period all social structure and institutions experienced structural change in terms of cultural, economic and political processes. In addition to this in this period the framework of the international system regarding economy and politics is established too. Important qualities of current modern societies are the speed of communication and interaction between its elements, its
\end{abstract}

\footnotetext{
* Yrd.Doç.Dr., İzmir Katip Çelebi Üniversitesi ,Sosyal ve Beşeri Bilimler Fakültesi ,Medya ve İletişim Bölümü, e-mail: ozkandev@hotmail.com

${ }^{* *}$ Yrd.Doç.Dr., İzmir Katip Çelebi Üniversitesi ,Sosyal ve Beşeri Bilimler Fakültesi ,Sosyoloji Bölümü, e-mail: parladir@hotmail.com
} 
transformational capacity and the extent of its scope. In this, it is possible to apprehend the basic cornerstones of today's information and communication age by analyzing the early modern period of England.

Keywords: Modern Society, Communication, Politics, England, Religion.

\section{Giriş}

Modernlik, diğer toplum modellerinden farklı olarak, tüm yeryüzüne yayılma eğilimindedir. Son iki yüzyıldır, modernliğin politik, ekonomik, hukuki ve kültürel uygulamaları, farklı tarzlarda, yaklaşık tüm mekânlarda, hayata geçirilmiştir. Modernlik, Modernizmin modern olmayan mekânların başlıca ideolojisi haline gelmesini temin emiştir. Modernliğin yayılma eğilimi, geliştirmiş olduğu kapitalist ekonominin sürekli büyümeyi gerektirmesinden ve sürekli yeni aktörlerin üretim ve tüketim süreçlerine dahil edilmesinin zorunlu hale gelmesinden, kaynaklanır. Bu nedenle modernlik doğduğu mekân olan Kuzey Avrupa'dan, hızla dünyanın tüm mekânlarına yayılmıştır. Bu yayılım sürecinde, modernlik, yeryüzündeki tüm politik ve ekonomik aktörleri "modern dünya sistemi" (modern world system) çerçevesinde birbirleriyle bağlantılandırmıştır. Bu kurumsal ve kişisel aktörlerin birbirleriyle bağlantılandırımasında, "kitle iletişim sistemleri" son derece verimli bir vasıta işlevi görmüştür. Modern toplum modelinin bu yayılım sürecinin başladığı yer endüstri devriminin hayat bulduğu modern İngiltere'dir. Gelgelelim, modernliğin neden olduğu çeşitli toplumsal ve ekonomik vakalar, genellikle, on sekizinci yüzyıldan hareketle kavranmaya çalışılmaktadır. Hâlbuki modern toplum modelinin kuruluşu on altıncı yüzyılın başlangııından on sekizinci yüzyılın ilk yarısına kadar geçen dönemde oluşmaya başlamıştır. Bu nedenle modern İngiltere'nin ilk dönemi, modernliğin neden olduğu kalkınma ve dinamizmin yanı sıra, tahakküm, kitleselleşme, kültürel erozyon gibi problemlerin kavranabilmesi için incelenmesi gereken başlıca temalar arasındadır.

İngiltere'nin modernleşme sürecindeki ilk dönemi iki yüz elli yıllık (1600-1850) bir dönemi kapsar. Tudor hanedanı (1485-1603) ve Stuart hanedanı (İskoçya'nın idaresi 1371-1603, İngiltere, İskoçya ve İrlanda'nın idaresi 1603-1714) tarafından idare edilen İngiltere'nin modernleşme pratikleri, önemli bir örnektir. Modernleşme pratikleri açısından, İngiltere'de politik aktörlerin oynadıkları rol önem arz etmektedir. VII. Henry (14571509) başta olmak üzere, VIII. Henry (1491-1547) I. Elizabeth (15331603), I. James (1566-1625) ve I. Charles (1600-1649) İngiltere'nin günümüze kadar gelen toplumsal yapısının temel yapı taşlarını inşa ettiler. I. Elizabeth'in çocuk sahibi olmamasından dolayı, ölümünden sonra en yakın akrabası olan İskoçya kralı I. James tahta geçmiştir. 1704 tarihinden 
sonra tahtı, Hannover hanedanından I. George devralmıştır. I. Charles'ın idamından sonraki on yıllık periyodda idareyi devralan Cumhuriyetçi idareden sonra, tahta geçen II. Charles (1630-1685), dış ilişkiler ve kolonyal politikalarıyla Britanya İmparatorluğu'nun gelişimini temin eden yolu açmışıı. Ayrıca İngiltere'de ilk defa on yıllık bir süre (1649-1658) ile cumhuriyet deneyiminin yaşanmasını sağlayan Oliver Cromwell (15991658) de İngiliz politik sisteminin kuruluş sürecinde önemli bir figürdür. $\mathrm{Bu}$ figürlerin tamamı İngiliz kamusu ve politikasının biçimlenmesinde belirleyici olmuşlardır.

Kapitalizmin genişleme eğiliminden dolayı bir dünya sistemi olarak biçimlenmesine neden olan temel niteliklerini analiz eden Wallerstein'ın (1974; 1980; 1989) "modern dünya sistemi" teorisi modern ekonominin yanı sıra, modern politik sistem ve kültürün yayılım eğilimlerinin incelenmesi açısından kullanışıdır. Ayrıca, modernleşme süreçlerinin belirli dönemlerinin nitelikli bir biçimde kavranabilmesine imkân sağlamaktadır. On altıncı yüzyııın başı ile on sekizinci yüzyılın ortası arasında geçen süreç, gerek İngiliz modernleşme pratiği ve kültürü, gerekse modern İngiliz toplumu ve politik sisteminin kuruluşu açısından son derece önem arz eder. Bu dönemde, hükümet, toplumsal yapı, kültür, politik değerler, ekonomi ve din sahasında etkili olan figürler ve gruplar İngiliz toplumunun kuruluşuna yön vermiştir. İngiliz toplumsal yapısının Britanya İmparatorluğu'nun modernleşme süreçleri boyunca egemen olduğu dikkate alındığında, "modern dünya sistemi"nin tesisinde örnek model olarak tüm dünyada farklı tarzlarda uygulamaya koyulduğu anlaşılmaktadır. Bu nedenle günümüzde egemen olan "modern toplum modeli"nin oluşumunda etkili olmuş bir tarihsel dönemin incelenmesi gerekir. Yeni "kitle iletişim sistemleri"nin ve "modern toplum modeli"nin oluşum süreci, günümüzdeki değişim ve dönüşümlerin rotasının kavranabilmesi açısından önem arz etmektedir.

Toplumsal yapılar, tarihsel bir süreçte, belirli kademelerden geçerek oluşmaktadırlar. Modernliğin değişimin hızını arttıran niteliği dikkate alındığında, İngiliz modernleşmesi ile her alanda gerçekleşen dönüşümün, yaşamın ayrımaz bir niteliği haline gelmesiyle başlayan dinamik sürecin toplumsal, politik, ekonomik ve kültürel yansımalarının ve etkilerinin analizi, günümüze dair nitelikli bir kavrayışın temin edilebilmesi için zaruridir. On altıncı yüzyılın sonundan itibaren, "zaman" dünyada başka bir hız ile akmaya başlamıştır. Daha önce insanlığın tanık olmadığı ölçüde dinamik bir biçimde ilerleyen "zaman"ın temposunu giderek arttırdığı da reddedilemeyecek bir realitedir. Özellikle yirminci yüz yılın ikinci yarısından itibaren etkileşimin, değişimin, dönüşümün ve iletişimin "kapsamı," "etkisi" 
ve "hızı" karşı konulamaz bir biçimde artmaktadır. Kuşakların yaşam tarzları, tutumları, alışkanlıkları ve dünyayı algılayış biçimleri, daha önceki dönemlerde hiçbir zaman görülmedik ölçüde farklılaşmaktadır. Bu durumun vuku bulmasında modernliğin temel yapı taşlarının oluşturulduğu on beşinci yüzyılın sonu ile on sekizinci yüzyılın ortasına kadar geçen süreçte yaşananlar belirleyicidir.

İngiltere'nin ilk dönemi, önemli politik ve kültürel aktörlerin yanı sıra dünya tarihini derinden etkileyen vakaların da yaşandığı bir sürece tekabül eder. İngiliz Reformasyonu (on altıncı yüzyı), İngiliz İç Savaşı (1642-1651) ve Britanya İmparatorluğu'nun (1583-1783) kuruluşu bu vakalardan en önemli olanları arasındadır. Ayrıca William Shakespeare (1564-1616) ve John Milton (1608-1674) gibi şairlerin yanı sıra, ilk demokratlardan John Lilburne'nin (1614-1657) de yaşadığı bir dönemdir. Everitt (1966: 56), modern İngiltere'nin ilk döneminin, öncesi ve sonrasında, toplumsal dönüşüm süreçlerinin gerçekleştiği zamanlar olduğu konusunda ana hatlarıyla fikir birliğine ulaşıldığını belirtir. Gerçekten de, bu dönemde yaşanan gelişme süreçleri dikkat çekicidir. Ekonomik kalkınma, politik kültür, toplumsal dönüşüm süreçleri ile edebiyat ve basım teknolojisindeki gelişmeler, toplumsal yapının yeniden biçimlenmesinde etkilidir. Tüm bu gelişmelerin etkisiyle okuma yazma alışkanlıklarından, ailenin ve cinsiyetler arasındaki ilişkilerin teşekkülüne kadar her alanda değişim yaşanmıştır. On beşinci yüzyılın sonunda başlayan transformasyon, tarihçilerin başlıca ilgi sahalarından birini oluşturur. Bu dönemde Ortaçağ’ın tüm düşünce yapıları ve kurumları toplumsal işlevlerini yitirerek çökmeye başlamıştır. Ekonomik gelişmeler ile eski kurumların işlevsizleşmesi krizlerin yanında, yeni avantajlar da sunmaktaydı. İdari yapı ise giderek merkezileşerek devlet ile toplum arasında yeni etkileşim tarzları yaratmaktaydı (Brodie, 1932:133).

İngiliz toplumsal yapısına dinamizm sağlayan en önemli etken kişiler arasındaki "iletişim" ve "etkileşim"in boyutunda ciddi bir artışın mevcut olmasıdır. İngiltere'nin ilk döneminde, yazım faaliyetleri ve entelektüel nitelikteki artış belirgindir. Basım faaliyetleri yanında, kişilerin birbirlerinin düşünceleri ile diğerlerinin hayat hikâyelerine dair ilgileri artmıştır. İngiliz tarihçiliği ciddi bir atılım gerçekleştirmiş ve ilgili literatür hızla genişlemiştir. Ingilizcede yayınlanan tarih eserlerinde yeni bakış açılarına, tartışmacı üsluba ve yeni temalara rastlanır. Klasik temaların yanında, politik ve kurumsal tarih, cinsiyet tarihi, toplumsal tarih, kültür tarihi eserlerinde dikkat çekici bir artış yaşanır.

Şüphesiz ki bütün insanlık tarihi günümüzün anlaşılabilmesi açısından önemlidir. Zira insani temel nitelikler, insanın farklı koşullarda nasıl tepkiler verdiği, ne gibi çözüm yöntemleri geliştirdiği ve toplumsal yapısını ne 
şekilde yapılandırdığının anlaşılmasıyla kavranabilir. Gelgelelim, "modern dünya sistemi"nin biçimlenmesinde doğrudan belirleyici olduğundan dolayı, ilk dönem İngiliz tarihinin incelenmesi modern toplumun yapısı ve işleyişinin kavranabilmesi için hayatidir. Modernlik zaman paradigmasını tamamen değiştirerek dün, bugün ve gelecek arasında ayrılmaz bir bütünlük olduğu inancının yerleşmesini sağlamışır. Modernliğin zaman paradigmasını dönüştürmüş olması, insanın kendisini ve bulunduğu zamanı dün ve gelecek ikiliğinde kavramaya çalışmasına yol açmışır. (a) "Temsili hükümet kurumları"nın nasıl oluştuğu; (b) kapitalist pazar ekonomisinin yapısı ve dinamikleri; (c) "hukukun üstünlüğü" kavramının nasıl hayat bulduğu; (d) bireysel özgürlük kavramı ve kolektif sorumluluk ideali; (e) dinsel fanatik düşüncelerin kademeli olarak politikanın dışına taşınması gibi, günümüzü çeşitli biçimlerde etkileyen anlayış ve vakalara dair nitelikli bir kavrayışın geliştirilebilmesi modern İngiltere'nin ilk kuruluş sürecinin anlaşılması ve yorumlanmasına bağlıdır. İlk defa, İngiltere'de yaşanan tüm bu gelişmelerin uluslararası etkileri olduğundan dolayı, "modern dünya sistemi"nin kişi, ulus ve kurum arasındaki iletişimi zorunlu hale getiren yapısının anlaşılabilmesi için, hayatiyet arz etmektedir.

İngiltere'nin, modernleşme ve endüstrileşmenin en önemli merkezlerinden biri olduğundan dolayı, küreselleşme ve "modern dünya sistemi"nin kavranabilmesi için dikkatle değerlendirilmesi gerekir. Ayrıca, unutulmamalıdır ki, İngiltere tarihi sadece İngiltere tarihi değildir. Kolonileşme politikalarını, sahip olduğu donanma gücünün tüm imkânlarını kullanarak en mükemmel bir biçimde devam ettirmiş olan İngiltere, aynı zamanda Kanada, ABD, Avustralya, Yeni Zelanda ve Hindistan'daki toplumsal, kültürel, politik ve ekonomik gelişmelerde doğrudan etkili olmuştur. Tüm dünya tarihinin ve toplumsal gelişmelerinin son dört yüzyıllık dönemini pek çok açıdan çeşitli şekillerde etkileyen ilk dönem İngiltere'si modern yaşam tarzlarının, kentlerin ve her şeyden önemlisi egemen hukuk ilkelerinin belirlenmesinde etkili olarak, dünyadaki tüm kişisel ve kurumsal öznelerin nasıl bir biçimde eşgüdümlü davranacaklarının genel çerçevesini çizmiştir.

On altı ve on yedinci yüzyıl İngiltere'sinde ortaya çıkan dini gelenekler günümüzde de etkisini tüm Anglosakson dünyasında devam ettirmektedir. Quakerism, Presbiteryenlik Baptism ve Bağımsız Cemaat Kilisesi (Congregational Church) gibi Hıristiyan mezheplerinin tümü, on altı ve on yedinci yüzyıl İngiltere'sinde vuku bulan toplumsal gelişmelerin birer neticesi olarak gelişmiştir. Amerika'ya göçte etkili olan tüm bu mezhepler, günümüz $A B D$ 'nin kültürel, politik ve kimliksel yapısının biçimlenişinde etkili olmuştur. Birinci dünya savaşından sonra ABD'nin uluslararası politikada ve 
ekonomide belirleyici başat faktör olmasından dolayı, her öznenin bir biçimde ABD'nin politik, ekonomik ve kültürel politikalarından etkilendiği göz önüne alındığında, ilk dönem modern İngiltere tarihinin güncel gelişmelerin yapısal analizi açısından ne derece önemli olduğu bir kez daha anlaşilır.

Bu makalede, "enformasyon toplumu", "iletişim çağı" "küreselleşme" kavramları ile nitelendirilen günümüz "modern dünya sistemi"nin yapısal niteliklerinin oluştuğu modern İngiltere'nin ilk dönemi incelenerek, modernlik ve yaratmış olduğu "iletişim merkezli" yenidünya analiz edilmektedir. On altıncı yüzyıldan on sekizinci yüzyıla kadar geçen süreçte, İngiltere'de yaşanan değişim ve dönüşümler dikkat çekicidir. On beşinci yüzylın sonunda kral mutlak bir biçimde İngiltere'yi idare etmekteyken, on yedinci yüzyıla gelindiğinde "meşruti krallığa" geçilmişti. On yedinci yüzyılda seçilmiş parlamenterlerin politik hayatın merkezinde yer aldığı bir sistem işlemekteydi. Ayrıca on yedinci yüzyılda İngiltere politik açıdan sadece İngiltere'den ibaret değildi. Bu yüzyılda İrlanda, İskoçya ve İngiltere'den oluşan bir birlik haline gelen İngiltere'de, yaşamın bütün sahalarında derin altüst oluşlar gözlemlenir. On beşinci yüzyılda Vatikan'a bağlı olan ve Ortaçağ Katolik uygulamalarını sürdürüldüğü İngiltere, on yedinci yüzyıla gelindiğinde Protestan mezhebinin kararlı ve mutlak bir biçimde uygulamaya geçirildiği en önemli merkezlerden biri haline gelmişti. İngiltere Kilisesi'nin kuruluşu ile birlikte Protestanlığın İngiltere'de dominant hale gelerek tüm dini uygulamaların karar merkezi haline gelmesi, İngiltere'nin Avrupa kıtasından politik bağımsızlığını sağlayarak, bir dünya imparatorluğu haline gelmesini temin eden kültürel ve ekonomik dönüşümlere neden olmuştur. Kapitalist pazar ekonomisi ve toplumunun oluşumu, ekonomik kültürün dönüşümü ile eşgüdümlü bir biçimde ilerlemiştir (Wrightson, 2000: 26). On beşinci yüzyılda yerel nitelikleri ağır basan tarım ve zanaat faaliyetlerine dayalı bir ekonomik yapıya sahip olan İngiltere, on yedinci yüzyılda ticaretin belirleyici olduğu bir pazar ekonomisine geçerek kapitalizmin tesis edilmesine olanak sağlayacak bir alt yapıya kavuşmuştu. $\mathrm{Bu}$ durumun temin edilmesinde, doğu ile Amerika arasında gerçekleşen ticarette kilit rol oynamasını sağlayan Atlantik Okyanusu'ndaki egemenliği etkili olmuştur. Bu sayede son derece geniş bir sahada ticari etkinlikte bulunma imkânı edinen İngiltere, dünya politikası ve ekonomisine yön verecek olanaklara kavuşmuştur. Okuryazar oranının hızla arttığı ve matbaa ile yayımclık faaliyetlerinin geliştiği İngiltere'de, özellikle on yedinci yüzyılın başından itibaren günlük gazete yaşamın ayrılmaz bir parçası haline gelmiştir (Baron, 2005: 41). On altıncı yüzyııın başı ile on sekizinci yüzyılın ortası arasında, her alanda göze çarpan farkların çarpıcılığı, modernliğin 
başlıca niteliği olan hız ve değişimin toplumsal yaşam üzerindeki mutlak etkisinden kaynaklanır.

On yedinci yüzylla gelindiğinde Londra kentsel dönüşümün, göçün, ticaretin ve entelektüel etkinliklerin merkezi haline gelmişti. Yirminci yüzyılın başında New York'un yaşadığı devasa dönüşümün benzeri on yedinci yüzyılda Londra'da yaşanmıştır. Avrupa'daki en büyük metropol haline gelen Londra, modern kentlerin inşasında kullanılan başıca model oldu. Kitlesel dönüşümün çarpıcı örneklerini sergileyen İngiltere ve Londra, toplumun dönüşüm doğrultusunda yeniden yapılanmasını da sağlamıştır. Gelgelelim toplumsal çatışmaların değişik tarzlarda sıklıkla yaşanmaya başlaması da on yedinci yüzyıl İngiltere'sine ait bir özelliktir. Toplumsal çatımalar tüm insanlık tarihi boyunca süreklilik arz eder. Ancak yeni ekonominin gereklilikleri, bir yandan sınıfları eşgüdümlü eylemde bulunmaya zorlarken, diğer yandan sınıflar arasındaki uçurumu arttırmışır. Politik sahada söz sahibi olan tüm taraflar kademeli bir biçimde "ortak iyinin" tesis edilmesi için çabalarken, kendi ilgi ve çıkarlarını da korumaya çalışmıştır.

İngiltere'de on altıncı yüzyılın başı ile on sekizinci yüzyılın ortası arasında yaşanan tüm gelişmeler modern dünyanın alt yapısını teşkil eden önemli faktörler arasındadır. Bu nedenle, bu iki yüz elli yıllık dönemin analizi, "modern dünya sistemi"ne dair nitelikli bir kavrayışın geliştirilerek, yirmi birinci yüzyıl toplumlarının başlıca niteliklerinin neler olduğunun yanı sıra, problemlerinin kökenlerinin nelerden kaynaklandığının tespitini sağlar. Bu makalede, günümüzde "iletişim"in tüm toplumsal işleyiş dinamiğini sağlayan temel faktör haline gelmesinin nedenleri, ilk dönem İngiltere'sinde yaşanan gelişmeler ile bağlantılandırımaktadır. Bu sayede parçaları arasındaki "iletişim" ve "etkileşimi" son derece dinamik bir yapı arz eden modern toplumların, gelişim süreci ile günümüzdeki gelişmeler arasındaki süreklilikler tespit edilmektedir.

\section{Modern İngiltere'nin İlk Döneminde Toplumsal Yapı ve Gelişmeler}

On altıncı yüzyılda insanların "toplumsal düzeni" algılama tarzları ile günümüzdeki algılayış arasında önemli farklılıklar mevcuttur. Gelgelelim, günümüzdeki toplumsal düzenin modern algılanış tarzının oluşumu, beş yüzyllık bir sürecin neticesinde hayat bulmuştur. Geleneksel olandan modernliğe doğru yaşanan toplumsal evrim çeşitli aktörlerin toplumsal olayların, kurumların ve yaşanan vakaların etkisiyle zaman içinde biçimlenmiştir. Sürecin biçimlenişinin temel dayanaklarına ışık tutan başlıca eserlerden biri Edmund Dudley (1948 [1509-1510]) (1462-1510) tarafindan kaleme alınan "The Tree of Commonwealth"tir. Dudley, VII. Henry'nin hükümdarlığı boyunca etkili olmuş başlıca politik figürdür. Önemli miktarda 
zenginlik edinmiş olan Dudley, VIII. Henry tahta geçtikten kısa bir süre sonra hapsedilmiştir. Duruşmasından sonra kuleye hapsedildiğinde, daha sonra idam edileceğini bilmiyordu (Harrison, 1972: 84). Yaklaşık bir yıl sonra idam edilen Dudley, adı geçen eserini hapishanede yazdı. Bu eser on altıncı yüzyılın anlaşılması açısından klasikler arasında yer almaktadır. Politika pratiğindeki tüm deneyimini eserine yansıtmış olması Dudley'in kullandığı kavramlar arasındaki kombinasyonunun, etkili olmasına neden olmuştur (Jones, 2000: 29). Bu eserde geçen anahtar kelimeler on altıncı yüzyılın anlaşılması açısından önem arz eder. Dudley, eserinde yeni kralın ve İngiltere'nin başarılı olabilmesi için yapılması gerekenlere yönelik bir kılavuz eser ortaya koymayı amaçlamıştır.

Dudley'in kullanmış olduğu başlıca kavram "commonwealth"tir. Bu kavram bir yandan politik yapıyı adlandırırken, diğer yandan "refah," "ortak iyi" ve "ortak çıkar" manalarını taşır. Dudley bu kavramı ele alırken çeşitli benzetme ve karşılaştırmalardan faydalanır. Ona göre "commonwealth" bir ağaca benzemektedir. Bu ağcın da diğer tüm ağaçlar gibi kökleri mevcuttur. "Commonwealth" ağacının kökleri "Tanrı sevgisi," "güven," "harmoni" ve "adalet"tir. Ayrıca bu ağacın da diğer pek çok ağaç gibi meyveleri vardır. "Commonwealth" insanlara "huzur," "refah" ve "itibar" sağalar. Harmoninin egemen olduğu "commonwealth"te insanlar arasındaki çatışmalar engellenir. Bu sayede sağlanan huzur ortamında insanlar refahlarını arttırabilirler. Refah ve huzur sahibi insanlar, kirli çıkar kavgalarına girmeyeceklerinden, itibarlarını koruyabilirler. Harmoninin temin edilebilmesi için, kralın yol göstericiliğinde hareket edilmesi, kralın da tüm toplumsal grupların çıkarlarını gözetmesi gerekir. Bu sayede çatışmadan uzak kalınarak toplumsal çıkar grupları arasında uyum ve eşgüdüm sağlanmış olur. Kralın ve idarecilerin kibirli tutumları, toplumsal düzenin çatışmalar ile bozulmasına yol açacağı gibi, idari mekanizmanın işleyişine de engel olur (1948: 62-63). Brodie (1932:144) Dudley'in ticari meselelere ve tüccarların artan önemine dikkat çektiğini belirtir. Tüccarların güç ve toplumsal işlevlerindeki artışla, aristokratlara, din adamlarına ve bürokratlara rakip olabilecek derecede önem arz etmeye başlamaları, dikkat çekicidir. Toplumsal aktörlerin konum ve işlevlerindeki dönüşüme paralel olarak, çeşitli sınıf çatışmalarının yaşanabilme intimali, İngiliz politik sınıfının, toplumsal harmoninin hangi düşünce tarzı, kültür ve kurumlar ile temin edilebileceğine odaklanmalarına neden olmuştur.

Dudley'e göre harmoninin sürdürülebilmesi için üç sınıfın çabaları önem arz eder. Bunlardan birincisi rahiplerdir. Rahipler, Tanrı'dan kralın ve halkın refah, huzur ve mutluluğunun devamı için yardım isterler. Herkesin iyiliği ve Hıristiyan değerlerinin tüm toplumda devam etmesi için çalışırlar. 
İkincisi aristokratlardır. Savaş zamanlarında kendi bölgelerini korumakla görevli olan aristokratlar, barış zamanlarında kralın egemenliğinin sürdürülmesini sağlar. Yoksulları korumakla görevli olan aristokratlar, centilmen karakterleriyle krala en iyi bir biçimde hizmet eder. Üçüncüsü ise "avam" olarak tabir edilebilecek sıradan insanlardır. Avam üyeleri kendi bölgelerini ve topraklarını en iyi biçimde işletmekle mükelleftir. Sürekli şikâyetçi olarak toplumsal düzeni bozmaması gereken avam, sebatkâr bir biçimde çalışmaya devam etmelidir. Krallığın huzur ve harmonisi avamın sebatkârca çalışmaya devam etmesine bağlıdır. Bu sınıfların nasıl yaşamaları ve toplumsal düzendeki konumlarının ne olması gerektiğini betimleyen Dudley, "düzen", "bağımlılık" ve "harmoni" kavramlarını sıklıkla kullanır. Şüphesiz ki bu kavramlar vasıtasıyla Dudley, komüniteryen ideallerini yansıtır. "Commonwealth" birbirine bağı olan sınıfların harmoni ve refahının sağlanabilmesi için vazgeçilmezdir. Ancak Dudley'in vizyonu komüniteryen nitelikler taşımasına rağmen, eşitlikçi değildir. Sınıflı bir toplumsal düzenin tesis edilmesini tavsiye eder. İş bölümünün daha nitelikli bir biçimde gerçekleştirilmesi amaçlanmakta ve sınıfların birbirlerine bağımlılı̆ı arzulanmaktadır. Ancak sınıfların birbirlerine bağımlı olmaları, hiyerarşik bir dizgede sabitlenmiş bir konumları olmadığı anlamına gelmez. Toplumsal düzenin sürdürülmesi için gerekli olan katkılarını kendi sınırları çerçevesinde yerine getirmekle mükellef olan her bir sınıf, "commonwealth"in sağlayacağı olanaklardan da kendi seviyeleri kadar pay alabilir (1948: 45-48).

Nisbet (1959: 17), ABD ve çoğu Batı toplumunda, diğer toplum yapılarının aksine, iktidar, statü ve refahın dağıımının sınıfsal analiz ile kavranabileceğini ileri sürer. İktidar, statü ve refah arasındaki ilişkinin, sınıflı toplumlardaki yapısı kompleks niteliktedir. Bu nedenle, özellikle batılı toplumlara dair nitelikli bir kavrayış geliştirebilmek için sınıfların toplumdaki konum ve işlevlerinin analizi zaruridir. İş bölümünün niteliğindeki artışa paralel olarak gelişimini sürdürmüş olan modern toplumlar açısından, değişimin hızı ile uyumlu bir "toplumsal düzen"in nasıl sağlanacağı hayati bir mesele olmuştur. Dudley, herkesin konum ve rolünün belirlendiği sınıflı bir toplumu idealize ederek "commonwealth"in huzur, istikrar ve güvenliğinin temin edilebilmesi için bir yol haritası çizer. Bu sayede sınıflı bir toplum olan İngiliz toplumu, modernleşme sürecini iş bölümünü giderek artan bir biçimde daha nitelikli hale getirerek temin etmiştir.

İngiliz toplumsal hiyerarşisinin en tepesinde kral yer alır. Kral, toplumdaki en soylu kişi olmanın yanında, en fazla toprağa da sahiptir. Ancak kralın egemenliğinin meşruluğu sadece en soylu kişi olması ve en fazla toprağı elinde bulundurmasından kaynaklanmaz. Ayrıca kral Tanrı 
tarafından atanmış bir kişidir. Kral ile doğrudan kan bağı olan herkes krallık Ailesi'nde yer alırlar. Kral ve ailesinden sonra gelen aristokratlar ve din adamları Lortlar Kamarasında yer alırlar. Din adamları VIII. Henry'e kadar Papa tarafından atanır. Kendi toprağı olan aristokratlar, kralın egemenliğini kendi bölgelerinde temsil eder. Toprak sahibi olmak ile soylu olmak arasında ayrımaz bağlar olduğuna inanilır. Soylulardan sonra gelen şövalyeler kralın ve ülkenin güvenliğini sağlamakla mükelleftir. Centilmenler ise yaşamını sürdürmek için çalışmak zorunda olmayan eğitimli kişilerden oluşur. Tüm bunlardan sonra ise "avam" gelir. Avam, tüccar, "çiftçi" (yeomen) ve zanaatkârlardan oluşur. Avamın önemli bir bölümünü oluşturan "Yeomen" sınıfı, I. Elizabeth ve Stuart döneminde, sayısı ve toplumsal etkinliği itibariyle hızla güçlenmiştir. Orta sınıfı oluşturan "yeomen"in toplumsal etkinliğindeki artış çok sayıda olanaktan faydalanmalarını sağlamıştır (Shepard ve Spicksley, 2011: 528). Avamın üyeleri genellikle kasaba ve köylerde ikamet ederler. Çiftçilerin bazıları kendilerini geçindirecek kadar büyük olan topraklara sahipken, önemli bir bölümü aristokratların topraklarında çalışır. Varlıklı tüccarlar kimi zaman centilmenler ile avam arasında, tam olarak belirlenmemiş bir konumda yer alırlar. Avamda yer alan ve "aile reisi" (husbandman) olarak adlandırılan çiftçiler, yoksul çiftçilerden oluşur. Tüm bunların altında ise hiçbir toprağı olmayan ve mülk sahiplerine çalışan iş̧̧iler yer alır. İşçilerin bir kısmı sürekli aynı mülk sahibinin yanında çalışırken, önemli bir kısmı sürekli iş ararlar. Gerçekten de Ortaçağ ve ilk dönem modern İngiltere'de işçiler ve çiftçiler yaşamlarını sürdürebilmek için sürekli hareket halindedir. Kussmaul, (1979: 329). Modern İngiltere'nin ilk döneminde bekâr erkek ve kızları çiftliklere kiralanmak suretiyle çalıştııımasını sıklıkla rastlandığını belirtir. Bir yıllığına kiralanan "hizmetçiler," (servants) İngiliz tarımsal üretiminde çalışanların yarıdan fazlasını oluşturmaktaydı.

İngiliz toplumunun hiyerarşik yapısı ailede de sürdürülür. Kadın tamamen ikinci sınıtır. Kadının ikinci sınıf olması Hıristiyan inancının erkeğe aile idaresinde mutlak hâkimiyet vermesinden kaynaklanır (Walker, 2008: 9). Kadının evlenirken aileye getirdiği mülkiyeti aile reisine aittir. Sadece evli olmayan kadınlar mülk edinebilir ve ticari sözleşmeye imza atabilir. Gelgelelim, Erickson (1990: 37) kadınların on altıncı yüzyıldaki ikinci sınıf konumlarını kabul eder, fakat 1550 ila 1850 yılları arasında kadınların giderek artan bir şekilde bağımsızıklarını elde ettiğini düşünür. Ona göre bu süreçte kadınlar hukuki ve ekonomik bağımsızıklarını kazanmaya başlamıştır. Shepard ve Spicksley, (2011: 527), modern İngiltere'nin ilk döneminde yaşın refah ve toplumsal statü üzerinde fazlasıyla etkili olduğunu belirtir. Bu manada gençler üçüncü sınıfı oluşturur. Aileden 
bağımsız hiçbir hakka sahip olamazlar. Çiftliklerde tamamen ücretsiz işçi olarak çalıştııılırlar. Zanaatkârların yanında çalışanlar kendi işletmelerini açana kadar, yıllarca düşük ücretlerle çalıştırıır. On altıncı yüzyılın başında doğum oranının fazlalığı ve yaşam süresinin kısalığı dikkate alındığında, nüfusun önemli oranını oluşturan avamda yer alan gençlerin, üretimin büyük bölümünü gerçekleştirmelerinin yanı sıra, son derece zor şartlarda yaşamlarını sürdürmek zorunda kaldıkları anlaşılmaktadır. Murphy (1986), modern İngiltere'nin ilk döneminde çocuk ve gençler arasında görülen intihar oranının yüksek seviyede olduğunu belirtir. Yaşam şartlarının zorluğu ve yalnızlık, çocuk ve gençleri intihara sürükleyen başlıca etkenlerdendir. Murphy'nin araştırmasına göre 1485 ila 1714 tarihleri arasında İngiltere'de 13.968 intihar vakası gerçekleşmiştir (1986: 260-261). Ancak bunlardan sadece 1.098 tanesinde intihar edenlerin yaşları kaydedilmiştir. Bu 1098 kişinin \%38'ini oluşturan 416 kişi yirmi bir yaş ve altındakilerden oluşmaktadır. Bu rakamlar, sınıfsal ayrım ve çatışmanın, tüm toplumsal gelişmelerle birlikte giderek arttığını göstermektedir.

Sınıfsal hareketlilik ve ayrımların neden olduğu toplumsal dinamizm, en bariz biçimde kasaba ve kentlerde gözlemlenebilir. Ekonominin ana motorunu tarımsal üretim oluşturmasına rağmen, kasabalar mesleki niteliği yüksek kişilerin ikamet ettikleri mekânlar olmaları itibariyle toplumsal hayatın ve dinamizmin merkezinde yer almaktaydı. Özellikle tüccar ve zanaatkârlar kendi geçimlerini topraktan bağımsız bir biçimde sağlamak zorunda olduklarından, görece bir otonomiye sahiptiler. İş bölümünün çeşitlendiği yerler olmaları sebebiyle mesleğinde uzman insanları bir araya getiren kasabalar, aynı zamanda uzmanlıklar arası eşgüdüm ile nitelikli üretimin sağlandığı mekânlardı. Din adamlarının ve sıradan işçilerin de ikamet ettiği kasabalar, bulundukları bölgenin dini merkezi olmanın yanında, her zaman çalışmaya hazır ucuz işgücünü barındırmaktaydı. Ayrıca İngiliz kasabaları ilerde sanayi devriminin en önemli ürünü olacak olan kumaş üretiminin gerçekleştirildiği merkezlerdi. Modern İngiltere'nin ilk döneminde kumaş üretimi "yün" malzeme kullanılarak gerçekleştiriliyor ve tüm Avrupa'ya ihraç ediliyordu. İngiltere'nin yün kumaş üretimindeki bu deneyimi Amerikan pamuğu ve motorun icadıyla bir araya gelince endüstri devriminin kapısı aralanmıştır.

Görüldüğü gibi İngiliz toplumu on altıncı yüzyılda keskin toplumsal ayrımlara ve sınıflara dayanmaktaydı. Ancak, tüm bu sınıf, cinsiyet ve yaş ayrımlarına rağmen, İngiliz toplumunun bir arada harmoni ile hareket etmesinin nasıl sağlanabileceğine dair düşünsel çabalar mevcuttu. Nisbet (1948: 765), modern devlet ile toplum arasındaki ilişkinin, diğer iktidar ve toplum yapıları ile karşılaştırıldı̆ında tamamen farklı nitelikler arz ettiğini 
düşünür. Modernlik tüm yerellik ve otonomilerin toplumsal güç ve etkinliklerini yitirmelerine neden olmuştur. Yerel nitelikli kimlik ve iktidar yapıları, modernliğin neden olduğu merkezileşme ile erozyona maruz kalmıştır. Kilise, aile ve toplulukların toplumsal etkinlikleri azaldıkça, devlet ile sınıflar arasındaki problemler toplumsal çatışmaların temel niteliklerini belirlemiştir. Yaşamın yerel niteliklerinin ağır bastığı ve insanların dış dünya ile iletişimlerinin son derece sınırlı olduğu bir toplumda, sınıflar arasındaki mesafe çok geniş olsa da, insanlar yaşamlarını kapalı bir çevrede sürdürdüklerinden, toplumsal çatışmalar süreklilik arz etmez. Bu nedenle on altıncı yüzyıl ile birlikte yapısal bir dönüşüm sürecine giren İngiltere'de, yenidünya görüşlerine ihtiyaç her geçen gün artmıştır.

Günümüzde, insanlar her gün kitle iletişim araçları vasıtasıyla dış dünyaya dair çok fazla sayıda veri elde eder. Hâlbuki modern İngiltere'nin ilk döneminde, dış dünyadan veri elde etmek sıra dışı bir olaydır. İnsanlar hayatlarını köy ve kasabalarıyla sınırlı kalarak sürdürür. Bu nedenle de "aile" toplumsal yapının çekirdeğini oluşturur. Bu dönemde "aile" kavramının manası ve içeriği ile günümüzdeki "aile" kavramı arasında keskin bir farklılık mevcuttur. Günümüzde "aile", daha çok, evlilik sözleşmesi ile bir araya gelmiş iki birey ve varsa on sekiz yaşına kadar onlar ile kalacak çocuklardan oluşur. Ancak aile on altıncı yüzyılda daha çok iktidar hiyerarşisinin en alt basamağını oluşturan ve bir çatı altında aile reisinin egemenliğinde yaşayan tüm kişilerden oluşur. Ailenin yaşamını sürdürdüğü çatının altındaki herkes, hizmetçilerde dahil olmak üzere, aile reisinin egemenliğine tabi olmak suretiyle ailenin üyesi olur (Kussmaul, 1979: 329-330). Kişiler, aile hiyerarşisindeki yerleri ne olursa olsun, ailenin gerçekleştirdiği üretime katılır. Tüm aile üyeleri, hiyerarşideki yerlerine göre refahtan pay alır. Görüldüğü gibi on altıncı yüzyıl İngiltere'sinde aile, aynı zamanda bir işletme ve üretim birimidir. Bu nedenle aile üyeleri arasındaki ilişkiler şimdiki aile yapılarıyla karşılaştııılığında daha kompleks niteliklere sahiptir. Bu nedenle, üretim faaliyetlerinin gerçekleştirildiği bir işletme birimi olan "aile," "hane" (household) olarak adlandırılmıştır.

Modern İngiltere'nin ilk döneminde insanlar aileden sadece aralarında kan bağı olan kişileri anlamazlardı. Ayrıca, "hane" üyesi herkesin aileyi oluşturduğu düşünülürdü. Bir lordun hanesinde bulunan tüm hizmetkâr ve işçiler, aileden kabul edilirdi. Bunda, üretim faaliyetinin haneler tarafından sağlanıyor olması ve hane dışında sürdürülen üretimin sadece zanaat işlerinden ibaret olması, etkendir. İngiliz toplum yapısında hane, aynı zamanda çiftlik, okul ve imalathane işlevlerini de görmekteydi. Bu kompleks niteliğinden dolayı, aile üyeleri arasındaki karşlıklı bağımlılık, günümüze nazaran çok daha fazladır. Cressy (1986: 68-69) ilk dönem 
modern İngiltere'sinde aile ve akraba ilişkilerinin yoğunluğuna dikkat çeker. Yaşam koşullarının ve toplumsal yapının neden olduğu gereklilikler, kişilerin aile ve akraba ilişkilerine önem vermelerine neden olmuştur. Hanenin pek çok işlevi yerine getiriyor olması, kendi içinde kompleks bir iş bölümünün ortaya çıkmasına da neden olur. Modernleşme, hanede gerçekleştirilen tüm etkinliklerin zaman içinde kamusal alana taşınmasıyla ilerlemiştir. Böylece aile sadece iki kişi arasındaki ilişkinin resmiyete kavuştuğu bir birime indirgenmiştir. Modern devletin daha etkin bir idari yeteneği elde etmesi, kendisi ile kişi arasında yer alan aile ve komünite benzeri aracı kurumları ortadan kaldırarak, bireyselleşmeyi mutlak gaye haline getirmek suretiyle idealleştirmiş olmasıdır.

Hanenin işleyişinin günümüz ailesinden farklı olması, kişinin yaşamını, gayelerini ve kimliğini inşa yönteminin de tamamen farklı olmasına neden olur. Kişinin ait olduğu hane ile kuvvetli bağlarının mevcudiyeti ve dış dünyada tek başına yaşamını sürdürmesini sağlayacak kurumsal olanaklardan mahrum olması, yaşam tarzını ve yaşamı algılayışını etkiler. Günümüzde bankacılık, sigorta ve emeklilik sistemlerinin kurumsal niteliğindeki artış, kişilerin kendi birikimlerini, geleceklerini ve yaşamlarını bağımsız bir biçimde kurgulamalarını sağlayan olanaklar doğurmuştur. Ancak on altıncı yüzyılda, bu olanakların hiçbiri mevcut değildi. Bu nedenle kişiler hane ekonomisine bağımlıydı. Bireyselleşmenin, toplumsal ve kurumsal olanaklarının sınırlı olduğu on altıncı yüzyıl İngiltere'sinde kişiler, yaşamlarını sürdürmek için yerel ekonomiye bağımlıydı. Bu durum onların haneden bağımsız olarak hareket edebilmelerinin olanaklarını sınırlandırıyordu. İnsanlar arasındaki iletişim süreçleri de yerel kaygı ve ilgilere bağımlıydı. Kişilerin kendi kaderlerini ait oldukları hane ve komünitenin amaç ve hedefleriyle ortaklaştırmak zorunda kaldıkları bir toplumsal düzende, yerellik belirleyiciliğini muhafaza eder. Kapitalist gelişmeler üretimin yanında tüketimin çeşitliliğini de arttıır. Bu sayede kişiler, modernlik ve kapitalizmin temin ettiği yeni bağlantı sistemleri vasıtasıyla yerel bağlamlardan koparak, daha geniş bir enfrastrüktürde kendi yaşamını inşa edebilme imkânına kavuşur. On dördüncü yüzyılın sonundan itibaren, endüstri devrimine kadar gerçekleşen çok sayıda dönüşüm, kişilerin yerel bağımlılıklarından bağımsızlaşmalarına neden olarak, toplumsal hareketliliği arttırmıştır (Fox, 1988: 112).

On yedinci yüzyılda İngiliz erkekleri toplumsallaşmanın, aile ve toplum hayatı için çok önemli ve iyi olduğunu düşünürdü. Bu dönemde arkadaşlık ilişkilerinin yoğunluğu dikkat çekicidir. Kişilerin yerel topluluk ve kimlik ile kuvvetli bağlar tesis etmesinin en verimli yolu, aynı topluluğa üye olan diğerleriyle yakın ilişkiler geliştirmesiydi (Westhauser, 1994: 518). 
Modern İngiltere'nin ilk dönemindeki toplumsal yapının çekirdeğini oluşturan ve üretim mekanizmalarının merkezinde yer alan hane, çevresindeki diğer haneler ve toplumsal yapının diğer aktörleri ile karşııkı bağımlılık ilişkilerine sahipti. Gerek modern İngiltere'nin ilk döneminde, gerekse Endüstri Devrimi ve sonrasında giderek çözülen hane, toplumdan izole olmuş bir biçimde varlığını sürdürmüyordu. Her hane toplumsal kurumlar ile birlikte toplumsal mekanizmanın işletilmesine bir biçimde katkı sağlıyordu. Bu nedenle, on altıncı yüzyıl İngiliz toplumuna dair nitelikli bir kavrayışa ulaşmak için, hane ve ailenin yapı ve işleyişinin yanında, hanenin diğer haneler ve toplumsal kurumlar ile etkileşim ve ilişkilerinin yapısal analizi zaruridir. Yerelliğin belirleyici olduğu koşullarda yerel kurumlar son derece etkilidir. Günümüzde hemen tüm kurumlar geniş bir ölçekte hareket edecek şekilde yapılanırlar. Hâlbuki insanlar arasındaki ilişkilerin köy ve kasaba çevresinde sürdürüldüğü ve yüz yüze iletişimin egemen olduğu koşullar altında hane, kurum ve bireylerin toplumdaki rollerinin yanında, işlevleri de farklıdır. Değişimin son derece yavaş olduğu yerellik koşullarında istikrar ve geleneğin egemenliği mutlaktır. Modernlik yerellikleri farklı mekânlar ile etkileşime zorladıkça politik, ekonomik ve kültürel değişim kaçınılmaz hale gelmiştir. Yerelliklerin dışa kapalı olduğu ve dış dünya ile etkileşimde bulunma olanaklarının sınırlı olduğu koşullarda, süreklilik yaşamı belirleyen başlıca nitelik haline gelir.

On altıncı yüzyılın başında İngiliz kasabaları birkaç aileyi kapsayan büyük bir aileyi andırmaktaydı. Gelenek sel yaşam kalıplarının, tüm kişiler tarafından çeşitli tarzlarda tekrarlandığı bu kasabalar, hayatın kesintisiz bir biçimde geçmişte nasılsa, gelecekte de devam edeceği izlenimi bırakır. Dış dünya ile bağlantı kanallarının sınırlığı ile kendiliğinden vuku bulan kapalılık, sürekliliğin imkânını yaratır. Komünitenin değerlerine çok önem verilen geleneksel İngiliz yaşam tarzından, nasıl modern hayatın kozmopolit yapısına geçildiği, toplumsal evrimin modern zamanlardaki hızının dönüştürücü niteliği ile izah edilebilir. Haneleri bir araya getiren kasabalar ve etrafındaki köyler, lort tarafından idare edilir. Lort idareyi örf, adet ve görgü kurallarına göre işletir. Lordun egemenliğindeki bölgedeki halk tarım arazilerini ekip biçer. Lordun egemen olduğu bölgenin merkezinde bulunan toprakları genellikle köleler ve işçiler ekip biçerken, merkezin dışında yer alan araziler, toprak sahibi ve kiracı aileler tarafında işletilir. Bu aileler yıllarca aynı toprağı ekip biçtiklerinden dolayı, toplumsal düzen istikrarını korur. Kiracılar bölgedeki uygulamaya göre ya ömür boyu, ya da yıllık olarak arazileri kiralayabilir. Yerel gelenek ve alışkanlıklar arazilerin nasıl bir biçimde kiralanıp işletileceğini belirler. Bu geleneksel alışkanlıklar uzun zaman dilimlerinde oluşmuş olduklarından, süreklilik arz ederler. Geleneksel 
uygulamaların yerlerine yenileri kolayca ikame edilemez. Hangi kuralların uygulanması gerektiğine tekabül eden geleneksel alışkanlıkların oluşumunda, zorunluluklar da etkilidir. Bölgelere göre, toprağın verimi ve sağladığı gelir değiştiğinden uygulamalar da farklılaşır. Gelenek, büyükbaba ve babadan devralınarak gündelik yaşam pratiklerinde tekrar edilir. Elbette ki gelenekler de değişir. Ancak değişimin hızı son derece yavaştır. Kuşaklar geleneğin değişimini doğrudan deneyimleyemezler. Geleneklerin değişimi, gözlemlenemeyecek kadar yavaş değişimlerin birikimi ile kendiliğinden gelişir. Tarımsal üretimin işbirliği ile gerçekleştirilmesi, yaşamdaki tüm aktörlerin davranışlarına olduğu gibi toplumsal faktörlerin niteliğine de yansır.

Dinin toplumsal yapı ve gündelik hayat üzerindeki etkileri toplum bilimlerinin başlıca ilgi sahalarından birini teşkil etmiştir. Gerçekten de din, toplumsal hayatın kültürel, tarihsel, edebi, retorik ve metin temalarına entegre olduğundan, özel ve kamusal hayatın biçimlenişinde etkili olmaktadır (Clymer, 2008: 555). Modern İngiltere'nin ilk döneminde, toplumsal hayat kilisenin etrafında gerçekleşir. Kilise cemaati toplumu oluşturur. Toplumsal yaşamın tüm yerel niteliğine karşın, kilise evrensel iradenin temsilcisidir. Kilise tüm zaman ve mekânlarda geçerli olduğuna inandığı kuralların öğreticisi olarak, toplumsal yaşama çeşitli şekillerde müdahale eder. Komşuluk ilişkileri cemaatin yaşamında önemli bir yer işgal eder. Yaşam dünyasındaki tüm aileler birbirinin komşusu olarak kabul edilir. Komşular arasındaki dayanışma toplumsal yapının temel dayanaklarından birini oluşturur. Kişilerin birbirlerine karşı sorumluluğu geleneksel yaşamın işleyişini sağlar. Gerek kilise, gerekse lort tarafından işletilen yerel iktidar toplumsal yapının sürekliliğini sağlayan dayanakları kontrol altında tutar. Gelgelelim insan, yaşamını içinde bulunduğu koşulların gerekliliklerinin ve yönlendirmelerinin çizdiği sınırlarda inşa etmek zorunda olsa da, iradesini bir biçimde özel hayatını ve kamuyu dönüştürmek için kullanır. Kendine çizilen sınırları olabildiğince zorlayarak, kendi özerkliğin elde etmek için çabalar. "İnsani kaygı ve ilgiler", insanın, yaşamın zorunluluklarına ve sınılamalarına rağmen, kendi egemenlik sahasını genişletme eğilimine kapılmasına neden olur. Bu nedenle gelenek, alışkanlık ve örf, insani değişim arzusunun zorlamalarıyla, tüm iktidar yapılarının zorlamalarına rağmen, dönüşüme maruz kalır.

Dudley'in, idamını beklediği bir yıla yakın süre içinde kaleme aldığı, İngiliz toplumunun politik yapısının ne olduğu ve nasıl olması gerektiğine dair düşünceleri, modern İngiltere'nin gerek ilk döneminde, gerekse imparatorluktan ulus devlete geçiş sürecinde, modernliğin uluslararası bir model olarak İngiltere'de biçimlenmesini sağlayan pek çok gelişme ve 
düşünceye öncülük etmiştir. Toplumun klandan ulusa uzanan evrim süreci devletin evriminin yanı sıra, insanın yeni gelişme ve olgulara uyum sağlama sürecine tekabül eder. Dudley İngiliz kralı ve toplumuna harmoniyle çatışmasız bir biçimde kişisel ve toplumsal hayatlarını sürdürerek refaha kavuşmalarını temin edecek bir kılavuz hazırlarken, İngiliz toplumsal yapısının geleneksel niteliklerinin gerekli altyapıyı temin ettiğini biliyordu. Her ne kadar, kralın mutlak egemenliğine dayalı bir devlet sistemi teşekkül etmiş olsa da, İngiltere'de egemenliğin bölgesel iktidarlar tarafından paylaşılması ve yerel iradelerin egemenlik sahalarındaki belirleyiciliği, iktidarın "paylaşılabilirlik" (shareability) niteliğinde olduğuna dair dayanışmacı politik bir bilincin gelişmesini sağlamıştır. Bu sayede modern demokrasinin iktidarın tüm halk tarafından "temsil" vasıtasıyla paylaşılmasını öngören politik yapısının temelleri henüz on altıncı yüzyılda oluşmaya başlamıştır.

İngiliz politik sistemindeki harmoniye önem veren dayanışmacı eğilimlerin dayanakları gündelik yaşam ve kültürde mevcuttu. Walter ve Wrightson (1976: 22-23), İngiliz toplumunda, on altıncı yüzyıl ile on yedinci yüzyılın başında, kişiler arasında dayanışmacı eğilimlerin varlığına dikkat çeker. Kıtlık tehlikesi yönetici sınıflar ile halk arasına eşgüdümlülüğün temin edilip sürdürülmesine olanak vermiştir. Alt ve üst sınıflar arasındaki ilişkinin devamlılı̆ı kıtlık problemine karşı, toplumsal düzenin bir teminat olarak görülmesinden kaynaklanır. Modern İngiltere'nin ilk döneminde kıtlık korkusu, toplumsal düzenin sürdürülmesi konusunda, başlıca motivasyon unsuru olarak ortak bilincin biçimlenmesinde rol oynamıştır. Bu dönemde İngiliz toplumu kıtlık ve açlığa tamamen engel olabilecek modern bilim ve teknolojinin imkânlarına sahip olmamasına rağmen toplumsal düzeni ve dayanışmayı temin ederek, kıtlık ve açlık problemiyle baş etmeye çalışmıştır (Walter ve Wrightson, 1976: 41-42). Örneğin, Sharpe (1981: 48), endüstri döneminin bir önceki dönemine tekabül eden modern İngiltere'nin ilk döneminde aile içi şiddetin zannedildiği kadar yoğun yaşanmadığını ileri sürer. Bu durum dayanışmacı eğilimlerin yerel niteliği güçlü topluluklarda fazla olmasından kaynaklanır.

Braddick (1991: 2), devletin sadece kurumsal bir fenomen olmadığını, fakat aynı zamanda insanlar arasındaki eşgüdüm ve normatif konsensüs tarafından meydana getirildiğini düşünür. Aynı zamanda devlet, insanlar arasındaki eşgüdümün ve normatif konsensüsün sürdürülmesinin garantörüdür. Bu çerçevede, modern İngiltere'nin ilk dönemindeki devlet yapısını inceleyen Braddick'e göre (1991: 3) İngiliz devletinin idari işleyişinin etkinliği ücretsiz yerel görevlilerin eşgüdümüne bağlıydı. Doğu İmparatorluklarında üretimde bulunan halk ile imparatorluk bürokrasisi 
arasına aracı sınıfların girmesine müsaade edilmediğinden, gerek hiyerarşik yapıları gerekse iş bölümünün niteliği modern ekonomi ve politikanın işleyişini sağlayacak bir alt yapının oluşmasına olanak vermez. Ancak, İngiliz toplumunun hiyerarşik yapısındaki çeşitlilik ise "iş bölümü"nün (division of labor) nitelikli bir biçimde gerçekleştirilebilmesini temin etmiştir. Modern ekonomi iş süreçlerinin ve üretim aşamalarının bölümlere ayrımasını gerektirir. Bu sayede seri üretim gerçekleştirilebilir. Bir ürünün ortaya çıkmasını sağlayan tüm aşamaların tek bir usta tarafından gerçekleştirildiği zanaata dayalı üretim modelinin yerine modern endüstriyel üretimin geçirilmesi için gerekli olan "iş bölümü" sadece sınıflı toplum yapılarında hayat bulabilirdi. İngiliz toplumu çeşitli sınıflara ayrılmış olma niteliğini on altıncı yüzyılda kesin bir biçimde sağlamıştı. Bu sayede modernleşme için gerekli kültürel ve ekonomik dayanakları edinmiş olan İngiltere'nin, toplumsal yapısını modern gereklilikler çerçevesinde yapılandırabilmesi mümkün olmuştur.

\section{Toplum ve Devlet Yapısının Üzerinde Oluştuğu Altyapı}

On beşinci yüzylın sonuna kadar İngiltere'de kentler ve kasabaların ekonomileri, yerel niteliklerini muhafaza etmekteydi. Birbirlerine entegre olmamış bir biçimde sürdürülen yerel ekonomik etkinliklerin, ülkedeki diğer bölgelerle ve uluslararası ticaretle bağları zayıftı. Ancak, on altıncı yüzyıldan itibaren kentler arasındaki ticarette bir canlanma gözlenir. Yerel pazarlar bölgenin merkezinde bulunurdu. Pazar, çevresindeki yerleşimleri ve tarımsal faaliyetleri birbirine bağlayan bir işleve sahipti. Birbirine yakın pazarlar birbirleriyle bağlantılıydı. Tüm pazarlar, tarım ürünlerine, ham maddelere ve zanaat ürünlerine gereksinim duymaktaydı. Pazarlar, kasaba hayatının önemli bir parçası olacak şekilde işlev görmekteydi. Bu dönem İngiltere'sinde pazar, toplumsal etkileşimin en yoğun şekilde yaşandığı mekândır (Postles, 2004: 42). Kasaba pazarlarının tamamı birbirleriyle ve bulundukları çevreyle yakın etkileşimdeydi. Pazarlar arasındaki karşııkı etkileşim ticaretin canlılı̆ını sağlamaktaydı. Haftanın farklı günlerine yayılan kasaba pazarları, üretici ve tüccarların bulundukları yerin yanında, çevredeki pazarlarda da etkinlikte bulunmalarını olanaklı hale getiriyordu. Ekonomi, pazarlar arasındaki etkileşim vasıtasıyla mobilize olurken, insanlar da ticaret yapmak, iş bulmak ve evlenmek gibi gerekçeler ile doğdukları mekândan ayrımaktaydı. Kasaba pazarları ve ekonomik merkezler arasındaki etkileşimin, on altıncı yüzyıldan itibaren, giderek artması toplumsal hareketliliği beraberinde getirmiştir. Bölgelerde kapalı ekonomilerin devam ettirilmesi olanaksız hale gelmiştir. Bulunulan mekânın geleneksel alışkanlıkları harici etkiler ile daha hızlı bir dönüşüm geçirmek zorunda kalmıştır. 
Bu dönemdeki İngiliz kent yapısı tek bir merkeze bağlıdır. Politik sistemin ve verginin toplandığı merkez olan Londra, ekonominin de ana motoruydu. Hiçbir kent Londra ile karşılaştırılamazdı. İngiltere'de ekonomi canlandıkça Londra ekonomi, popülasyon ve politik açıdan giderek daha fazla büyümüştür. Çevresindeki ekonomik faaliyetlerin artışı Londra'nın daha fazla canlanmasına neden olmuştur. Londra'nın etrafında yer alan Leicester, Cambridge, Oxford, Coventry ve Northampton gibi merkezlerde "konaklama yeri" (inn) sayısının hızla artması (Everitt, 1966: 69-70) ticari hareketliliğin önemli bir göstergesidir. Gıda ve diğer tüm ham maddelerin temin edilebildiği bir pazar olan Londra'ya çevreden mevcut ürünlerin tamamı aktarımaktaydı. Londra, politik merkez olmasının yanı sıra, coğrafi avantajlara da sahipti. Denizden, nehir yollarından ve karadan taşımacılığın kolay olması, Londra'nın bir taşımacılık merkezi haline gelmesine yol açtı. Ayrıca, Londra ülkedeki diğer tüm bölgeye nazaran, çok daha fazla sayıda avantaj sunmaktaydı. Hammaddelerin işlenerek daha değerli hale gelmesini sağlayacak üretim alt yapısına sahip olmanın yanında, nitelikli insan gücüne de sahip olması çekiciliğini arttırıyordu.

İletişim ve taşımacılık sistemlerindeki gelişmelerin etkilerinin kapsamı, toplumsal yapıyı, kişilerin yaşam tarzlarını, kültürel etkileşimin boyutunu ve devlet sisteminin biçimlenişini içerir. İngiltere bürokratik idare sistemini Fransa'dan daha önce geliştirmiştir. Bunda İngiltere'nin etkili taşımacılık ve iletişim sistemlerini çok daha hızlı geliştirmesinin önemli bir payı bulunmaktadır. On sekizinci yüzyıla gelindiğinde İngiliz devleti Avrupa'daki rakiplerine kıyasla çok daha etkili ve bürokratik bir yapı kazanmıştı (Kiser ve Kane, 2001: 217). Ayrıca, Bernstein'a (1997: 72) göre, on yedinci yüzyılda püritenlerin dünya realitesini kabul ederek, pratik gereklilikleri dikkate almak suretiyle yaşamı biçimlendirme eğilimleri ticaretin gelişmesine önemli katkı sağlamıştır. Bu sayede Kuzey Batı Avrupa giderek artan bir biçimde üretim ve ticaretin merkezi halene geldi. Baltık Denizi'nden gelen kereste ve demir, Akdeniz'den gelen zeytinyağı, Güney Amerika'dan gelen gümüş ve şeker, Kuzey Avrupa'ya getirilerek pazarlanmaya başladı. İngiltere, Bristol, Londra, Hull ve Southampton'daki limanlarıyla, uluslararası ticaretteki etkinliğini giderek arttırdı. Rollison (2001: 167) Íngiltere'de on dördüncü yüzyıldan on yedinci yüzyıla kadar gözlemlenen en dikkat çekici toplumsal hareketliliğin, eski ortaçağ kentlerinden tekstil üretiminin yoğunlaştığı kentlere doğru yaşanan göç olduğunu vurgular. Bu süreçte kumaş üretimindeki dikkat çekici artış toplumsal hareketliliği de arttırmıştır.

Ancak Londra'nın önemini arttıran asıl faktör, uluslararası ticaretin bağlantı noktası olmasıdır. Hollanda ile Londra arasında deniz 
taşımaclığının sürekliliği, Avrupa ile İngiltere arasında yapılan ticaretin en önemli limanının Londra olmasını sağladı. Akdeniz kıyısından temin edilen çok sayıda ürün Hollanda'dan gelmekteydi. Basım faaliyetleri ve kitap pazarı için başıca gereklilik olan kâğıdın Hollanda'dan temin ediliyor olması, üretim ve ticaret açısından Avrupa ile kurulan bağın önemini gözler önüne serer. Hollanda, deniz ticaretindeki etkinliği geniş çaplı olduğundan, sahip olduğu taşımacılık ağıyla, İngiltere'nin uluslararası ticarete entegre olmasını temin etti. Gelgelelim Hollanda ile İngiltere arasındaki bu ticari etkileşim, ilerleyen süreçte ekonominin sınırlarını aşmışıı. Protestan değerlerinin en önemli merkezlerinden biri olan Hollanda vasıtasıyla yeni dini kavrayış ve değerler, İngiltere'ye taşınmıştır. Ancak Londra'nın ticari ve politik etkinliğinin artmasını sağlayan asıl faktör göçmenlerin yeni yaşam kurmak amacıyla tercih ettikleri başlıca adres olmasından kaynaklanır. Londra, toplumsal hareketliliğin gelişime sebep olduğunun başlıca göstergelerini sergiler. İngiltere genelinde doğup büyüdükleri mekânlardan ayrılarak yaşam gücünün sınırlarını zorlamak isteyen göçmenler, Londra'ya önemli bir enerji katmıştır.

On altıncı yüzyııın başından itibaren toplumsal hareketliliğin ve parçalar arasındaki entegrasyonun hızlı bir biçimde artması, karşı̧ıklı bağımlılık ilişkilerinin kompleks bir yapı kazanmasına ve çalışma ağlarının gelişmesine neden olmuştur. Toplumsal entegrasyonu beraberinde getiren ekonomik entegrasyon, ulaşım rotalarının tesis edilmesiyle coğrafi entegrasyonun da gerçekleşmesine yol açmıştır. Bu süreçte Aristokrasi de önemli bir rol oynamıştır. Politik bölgelerin eşit temsilcileri olarak, iktidar merkezindeki eşgüdümlü etkinlikleri, İngiliz toplumsal ve ekonomik yapısının harmonisini olanaklı hale getirmiştir. İnsanlar toplumsal ve ekonomik açıdan diğer bölgeler ile karşııkı bağımlılık ilişkileri geliştirdikçe, kendilerini yerel kimliklerinin yanında, zamanla oluşmaya başlayan ulusal kimlik ile ifade etmeye başlamıştır. Wrightson (1982), İngiliz toplumunda yaşanan dönüşümü, yerel ve bölgesel komünitelerin ulusal ekonomi ve kültüre entegre olmaya başlamalarıyla açıklar. Farklı ölçekte gelişmiş yerelliklerin birbirlerini çeşitli şekillerde etkiledikleri on altıncı yüzyllın başlangıç döneminde, modernliğin oluşumunu sağlayan yeni dayanaklar eski toplumsal ve ekonomik yapılarda, kendiliğinden, yavaşça oluşmaya başlamıştır. Bunda insanların diğer mekânlardakilerle birlikte daha yoğun işbirlikleri geliştirmeleriyle, yerelliklerinden koparak daha geniş bir enfrastrüktürde kendilerini tanımlamaları etkili olmuştur. Yerelde tamamen entegre olmuş topluluklar, birbirleriyle karşılıklı etkileşime geçtikçe kendilerine ve topluma dair kavrayışları da dönüşmüştür. Londra merkezli oluşan yeni ekonomik ve toplumsal faaliyetler, toplumu oluşturan tüm kişi 
ve sınıflar arasındaki "iletişim" ve "etkileşim"in artmasıyla dinamizmini güçlendirmiştir. İletişimdeki artış İngiliz modernleşmesini olanaklı kılan en önemli faktör olarak görünmektedir. Ekonomik ve politik bağlantıların sürekliliği iletişim ve etkileşim vasıtasıyla temin edilmiştir. Ekonomik ve kültürel yaşamı doğrudan etkileyen "iletişim"deki artış, politikadaki karar alma ve temsil sistemlerinin dinamik bir yapıya kavuşmasına neden olmuştur. Ancak İngiliz modernleşmesinin ana sürükleyicisi olan ulus bilinci, sadece ticari bağlantılardaki artışla değil, fakat daha çok politik ve dini faktörlerin etkisiyle gerçekleşmiştir. Tudor hanedanı egemenliği süresince vuku bulmuş olan politik ve dini sahadaki gelişmeler, İngiliz modernleşme pratiğinin biçimlenmesinde etkili olmuştur.

İktidarın yapısının ne olduğu ve nasıl işletildiği tüm toplumsal yapının işleyişini etkilediği gibi, kişilerin gündelik hayatlarındaki tutum ve davranışlarının biçimlenişinin yanı sıra, yaşam tarzlarını ve amaçlarını belirleme süreçlerini de etkiler. Bu nedenle iktidarın yapılanışı ve işleyişi toplumsal yapının biçimlenişinde doğrudan belirleyicidir. İngiliz toplumunun temel niteliklerinin biçimlenişinde iktidar sistemindeki dönüşümler etkili olmuştur. İngiliz tarihinde, VII. Henry'nin III. Richard'ı, 22 Ağustos 1485'te gerçekleşen Bosworth Meydan Savaşı'nda yenilgiye uğratarak tahta geçmesi, en önemli kilometre taşlarından birini oluşturur. Zira bu savaşla, VII. Henry, Tudor hanedanının yüzyıldan fazla sürecek hükümranlığının politik ve ekonomik alt yapısını inşa etmeye başlar. Tudor hanedanını kuran VII. Henry'nin oğlu VIII. Henry'nin gerçekleştireceği uygulamaların tüm İngiliz toplumunun ekonomik ve politik yapısını derin bir dönüşüm sürecine sürüklediği dikkate alındığında, on beşinci yüzyııın son döneminin, İngiliz politikası açısından ne kadar önemli olduğu bir kez daha anlaşılmış olur. Tudor hanedanının ilk dönemi iktidarın sağlamlaştııılıp çeşitli uygulamalarla pekiştirildiği bir süreçtir. Tudorlar yeni rejimlerini iktidara geçirip sağlamlaştırmak için önemli çaba gösterdi. İngiliz politik yapısında, bir yandan iktidarın meşruluğunu muhafaza ederken, diğer yandan politikanın başıca aktörü olan Aristokrasinin hanedana bağlılığını sağlamanın çeşitli güçlükleri mevcuttu.

Elbette ki iktidar, sadece hukuki meşrulukla ve halk ile Aristokrasinin bağlıı̆ıyla sürdürülemez. İktidarı oluşturan çeşitli kaynakları mevcuttur. Bunlardan en önemlilerinden biri ekonominin, iktidarın istikrarını sağlayacak bir biçimde, refahın sürdürülebilirliğini temin etmesidir. Ayrıca iktidarın askeri, politik ve ideolojik kaynakları ile ekonomik istikrar ve meşruluğunun, halkın ve Aristokrasinin bağılığını temin ettiği göz önüne alınacak olursa, bunların hepsinin birden iktidar yapısı ve işleyişi tarafından kapsandığı anlaşıır. Yönetim biçiminin nasıl oluşturulacağı tüm rejim değişikliklerinde 
gündeme gelir. İktidar dengelerinin yeniden yapılandığı rejim değişiklikleri, aktörlerin konumlarındaki değişimleri zorunlu kılmanın yanında, kurumsal değişiklikleri de kapsar. Tudor hanedanının iktidardaki egemenliğini tesis etme süreci ve iktidarı işletme tarzı çok sayıda kurumsal değişimi ve aktörlerin konumlarının yeniden yapılanmasını gerekli kılmışıı. Kuşkusuz, kral İngiliz yönetim biçiminin merkezinde konumlanmıştır. Kral iktidarın ideal bir biçimde işletilebilmesi için huzur ortamını tesis etmekle mükelleftir. İngiliz politikasında huzurun sadece adalet ile tesis edilebileceğine dair kültürel dayanaklar mevcuttu. Adalet hukukun mevcudiyeti ile tüm toplumsal aktörlerin konumlarından kaynaklı haklarının güvence altında olmasıyla gerçekleştirilebilir. Ayrıca on beşinci yüzyıl İngiltere'sinin politik yapısında kral, Vatikan'a destek olmakla mükellefti. Papa ile kral arasındaki ilişki kralın mutlak otoritesinin sarsılmasına engel olacak şekilde, Papa'nın sadece tavsiyelerde bulunabileceği tarzda düzenlenmişti. Tüm bunlar kralın egemenliğini mutlak bir biçimde tesis ederek sürdürebilmesini sağlayan başlıca unsurlardı. Kralın otoritesinin mutlaklığı politik yapının niteliğini belirliyor olsa da, çeşitli zorunluluk ve kısıtlamalar iktidarın işleyişini sınırlandıır. Bu sınırlamalardan en önemlilerinden biri, Aristokrasi ve halkın beklentileridir. Ayrıca anayasal kurumlar ve gelenekler da kralın iktidarını işletme sürecini sınırlandırır. Bunların yanında, kral önemli kararlarını alırken, aristokratlardan oluşan "danışma meclisi"nin (konsül) tavsiyelerine başvurur (Rose, 2011: 47). Kralı sınırlandıran bir diğer önemli faktör ise örf ve adetlere dayanan hukuktur. Yüzyıllar içinde oluşmuş olan belirli kaidelere dayanan hukuka aykırı hareket etmek kralın egemenliğini ve meşruluğunu sarsar.

"Danışma meclisi" on sekizinci ve on yedinci yüzyıl İngiltere'sinde eşgüdümlü politik etkinliği temin eden başlıca müzakere kurumudur. Kralın mutlak otoritesi, kararlarını yereldeki elitler ile müzakere ederek almasıyla hayata geçer. Burada krallığın ikili niteliği mevcuttur. İlk modern krallar aynı zamanda Reformasyon döneminin krallarıdır ve dinsel otoriteyi, kademeli bir biçimde, egemenlikleri altına almışlardır. Ancak, krallar, iktidarlarının meşruluğunu ve işleyişini yerel elitlere danışarak, kuvvetler arasında eşgüdümü sağlamakta gördüler (Cressy, 1986: 47-48). "Danışma meclisi"nin yanı sıra, İngiliz politik sisteminin en önemli aktörlerinden bir diğeri olan Parlamento, kralın iktidarını işletme sürecinde etken alan başlıca faktörlerdendir. Parlamento, kral, Lortlar Kamarasında bulunan Aristokrasi ve avamın temsilcilerinin belirli bir takvime göre bir araya gelmeleri ile oluşur. İngiliz politik sisteminde, toplumunun sınıflı niteliği dikkate alınarak, tüm ülkedeki bölge ve sınıfların parlamentoda temsil edilmesi temin edilmeye çalışımıştır. Ortak adet ve geleneklerin bir uygulaması olarak 
ortaya çıkan hukukta belirli ölçülerde değişiklikler yapmak, parlamentonun başlıca etkinliğidir. Ayrıca nelerden ne kadar vergi alınacağına dair kararlarda parlamentonun rızasının alınması zaruridir. Bu sayede kralın temsil ettiği iktidarın meşruluğu ve egemenliği zedelenmeden yönetebilir.

Görüldüğü gibi, Dudley'in de önem verdiği tüm hususlar, İngiliz politik sisteminde gözetilmiştir. Tüm sistem meşruluğun ve iktidarın egemenliğinin tesis edilmesine odaklanmış görünmektedir. İktidarın en tepesinde yer alan kralın karakteri tüm sisteme yansır. Gelgelelim, iktidarın kralların kişisel tercihlerinden bağımsız bir biçimde işlemesini temin eden kurumsal yapılar, alışkanlıklar, gelenekler ve hukuki uygulamalar devletin yönetim tarzının ve enfrastrüktürünün istikrarını temin eder. İktidarın işleyişini sağlayan tüm aktörlerin uymak ile mükellef oldukları kaideler vasıtasıyla yönetimin harmoni ile gerçekleştirilmesi, toplumsal harmoninin güvencesidir. Sınıfların parlamentoda temsilleri sayesinde, iktidarın en tepeden avama kadar kademeli bir biçimde yansıması sağlanmaya çalışlarak, toplumsal bütünlüğün ve entegrasyonun tesis edilmesi, İngiliz politik sisteminin ana niteliklerinden biridir. Kral ve merkezde yer alan bürokrasi ile yereldeki uygulamaları sürdürerek iktidarı temsil eden Aristokrasi, eşgüdümlü olarak iktidarı işletir. Kral ile Aristokrasi arasında eşgüdümün mevcudiyeti askeri teşkilatın yapısından dolayı büyük önem arz eder. Kralın muhafızlarından başka, merkezde büyük bir ordusu bulunmaz. Savaş gündeme geldiğinde, yereldeki aristokratların kendi hanelerinin üyelerini silahlandırarak bir araya gelmeleriyle "ordu" meydana gelir. Askeri gücün kralın egemenliği altındaki çeşitli parçaların bir araya gelmeleriyle oluşması politik dengenin korunmasına katkıda bulunur.

Askeri teşkilatlanmanın parçalı niteliğine rağmen, Tudorlar egemenlikleri altında bulunan güç dengesinin bozulmasına müsaade etmemeye dikkat ettiler. Bu nokta da on altıncı yüzyıl İngiltere'sindeki politik ve toplumsal yapının şekillenmesinde "Güller Savaşı"nın etkileri dikkatle değerlendirilmelidir. "Güller Savaşı" iktidar dengesinin VI. Henry'nin aleyhine olacak biçimde York dükü Richard, Warwick kontu Richard Neville lehine sarsılmasıyla başlamıştır. İngiltere, güçlü aristokratların, kralın egemenliğinde tesis edilmiş olan güç dengesini bozmalarından dolayı, 1455 ila 1485 yılları arasındaki dönemi iç savaşla geçirmiştir. $\mathrm{Bu}$ nedenle Tudor hanedanı üyeleri güç dengesinin bozulmasından ve Aristokrasinin kendi egemenliklerine alternatif oluşturacak derecede güçlenmesinden endişe etmiştir. Güç dengesini korumakta ısrarcı davranmalarının en önemli sebebi, iktidar ve toplumun istikrar ve harmonisi ni sağlama kaygısıdır. Bu harmoniyi sağlayan en önemli kurum parlamentodur. Tüm ulusu ortak ve eşgüdümlü bir şekilde 
kendi yaşamlarını biçimlendirmek için etkinlikte bulunmalarını temin eden parlamento, her ne kadar kralın paraya ve yeni yasalara ihtiyacı olduğunda sıklıkla toplansa da, birlikte iş yapma ve iktidarı paylaşma alışkanlığının, geleneğin bir parçası olmasına yol açmıştır.

Modern İngiltere'nin ilk döneminde toplumsal yapının şekillenmesinde, kralın, sınıfların, bürokrasisinin ve devlet yapısın yanında, Kilise de önemli bir faktör olarak rol oynar. İngiltere Kilisesi'nin, Roma Katolik Kilisesi'nden ayrıldığı 1534'e kadar geçen süreçteki Kilise'nin işlevleri ile bağımsızlık kazandıktan sonraki işlevleri birbirinden farklıdır. Kilise Hıristiyan doktrinlerinin kişilerin gündelik yaşamlarına, kamuya yansıması için gerekli tüm faaliyetleri yerine getirir. Öğretilerinin toplumun tüm kesimleri tarafından bilinmesini sağlamak için tüm araçları kullanır. Mimari bu araçlardan en önemlisidir. Okuma yazma oranının düşük olduğu bir toplumda duvar süslemeleri başlıca öğreti vasıtası olarak kullanılır. Kilisenin elinde bulunan kaynaklar vasıtasıyla en nitelikli mimari örneklerinin kent ve kasabaların merkezinde konumlandırıması, toplumsal yaşamı biçimlendiren mimarinin kamusal yaşamı doğrudan etkilemesine neden olur. Ayrıca Kilise toplumu kayıt altına alır. Evliliğin meşruluğunu sağlaması ve cemaatini kayıt altında tutması, topluma dair tüm verileri elinde bulundurma imkânı edinmesine neden olur.

Kilisenin toplumsal işlevlerinin kapsamının genişliği dikkate alındığında, krallık otoritesi ile Kilise arasında çatışmanın ve ilerleyen aşamada ayrışmanın gerçekleşmesinin kaçınılmazıı̆ı kolayca kavranabilir. Avrupa politikasındaki gelişmeler ve İspanya İmparatorluğu'nun yükselişi gibi harici etkenlerin de rol oynadığı İngiltere Kilisesi'nin Roma Kilisesinden ayrılması çok sayıda politik ve toplumsal değişime yol açmıştır. VIII. Henry'nin özel hayatındaki gelişmelerden, Avrupa devletlerinin ilgi ve çıkarlarındaki çatışmaların merkezi bir dini iradeye bağlı kalınmasını giderek daha zor hale getirmesine kadar çok sayıda faktörün çeşitli şekillerde etkilediği İngiliz Kilisesi'nin bağımsızlaşması, İngiltere'nin uluslaşması sürecinde en önemli kilometre taşıdır. İngiltere Katolik Kilisesi'nden bağımsızlaşarak kendi özerkliğini tesis ederken, toplumsal alanda, zorlayıcı kurumsal dini ilkelerin yerine, özyönetim ve özgür bireycilik ikame edilmiştir (Clymer, 2008: 553).

İktidarın ve ekonominin yapısal dönüşümü, toplumsal altüst oluşları beraberinde getirir. Kişiler toplumsal yaşamın nasıl sürdürüldüğüne dair verileri yaşam pratiklerinde edinirler. Geçmişten devraldıkları verilerin geçersiz hale gelmesi toplumsal problemlerin ortaya çıkmasına neden olur. VIII. Henry'nin iktidarında gerek iktidarın yapısı ve işleyişindeki gelişmeler, gerekse ekonomik kalkınma, refahın sınıflar ve kişiler arasındaki 
bölüşümünü, doğrudan etkilemiştir. Özellikle orta sınıfın yükselişi ve refahtan daha fazla pay almaya başlaması, nüfus artışına bağı olarak eski toplumsal dengeleri sarsmıştır. Tüm toplumsal aktörler konum ve işlevlerini yeniden yapılandırmak zorunda kalmıştır. Geleneksel hayatın sağladığı güvenceler, dinamik altüst oluşların sürekliliğinden dolayı geçersizleştikçe, orta sınıfın yükselişine paralel olarak, yoksulluk da yaygın ve görünür hale gelmiştir. Orta sınıfın tüketim potansiyelindeki artış fiyatlarda artışa sebep olur. Ticaret toplumunun doğuşuyla, kentleşmede yaşanan artış ile "tüketim" yeniden yapılanır (Pennell, 1999: 550). Sürece ayak uyduramayanlar yoksullaşırken, iktidarın ve ekonominin yeniden yapılanmasından dolayı ortaya çıkan yeni olanaklardan faydalanabilenler, toplumsal konumlarını ve refahlarını arttırır. Bu durum toplumsal gerilimlerin artmasına neden olur. Özellikle lortlar ile köylüler arasındaki gerilimin arttığı gözlemlenir. Fiyatlardaki yükseliş, piyasaya ürün arz etmenin en önemli vasıtası olan tarım arazilerinin önemini arttırır.

McRae, (1993: 29) modern İngiltere'nin ilk döneminde toplumsal düzende, önemli dönüşümler yaşanmasının başlıca sebeplerinden birinin nüfus artışı olduğunu düşünür. Bu dönemdeki hızlı nüfus artışı yeni tarım arazilerinin açılmasına neden olmuştur. Genellikle ormanlık araziler tarım arazilerine dönüştürülmeye çalışımıştır. Nüfus artışının ihtiyacını karşılayacak derecede yeterli gıda kaynaklarının mevcut olmaması enflasyonu arttırdığından tarımsal üretim daha cazip hale gelmiştir. Tarım arazileri gibi üretim kaynaklarının yeniden yapılanması toplumsal ve ekonomik dönüşümleri hızlandırır. Wrightson ve Levine (1995), Essex'te bir köy olan "Terling" özelinde, on sekizinci yüzyılın başında İngiltere'deki toplumsal ve ekonomik dönüşümü analiz eder. Din, toplumsal yapı, toplumsal kontrolde meydana gelen dönüşümlere odaklandıkları çalışmalarında, nüfus artışının işçi miktarında artışa neden olmasının, kültürel ve ekonomik kutuplaşmalara neden olduğunu ileri sürerler. Toplumsal ve ekonomik dönüşüm hızının artması ile sınıfsal kutuplaşmaların bir araya gelmesi, geleneksel yaşamın sürdürülebilirliğinin olanaklarını zayıflatır. İnsanlar yaşamlarını, geçmişte olduğu gibi sürdürememeye başladıkça, "geçmişin muhafaza edilip yeniden canlandırıması çabası" ile "dönüşümü hızlandırarak süreci bir an önce neticelendirme" eğilimleri arasındaki çatışma şiddetlenir. İnsanların yerelliklerinin dışında yaşamlarını inşa edebilme olanaklarındaki kademeli artış, bireyciliğin gelişmesine imkân veren kültürel alt yapının yaşam pratiklerinde oluşmasını sağlar. Buna karşı komüniteryen yaklaşımlar toplumsal istikrarı ve güvenliği elde etmek maksadıyla yaygınlaşır. 
İngiltere'nin uluslararası ticaretin bir parçası olması ve ürünlerin dolaşımındaki artışa paralel olarak ticarette yaşanan artış toplumsal dönüşümün hızını giderek arttırmıştır. 1547'de VIII. Henry'nin ölümünden sonra, toplumsal ve ekonomik problemler ile geçen VI. Edward (15371553) ve I. Mary'nin (1516-1558) hükümdarlı̆ından sonra tahta çıkan I. Elizabeth'in (1533-1603) dönemi toplumsal dönüşüm süreçlerinin giderek hızlandığı bir süreçtir. Yirmi beş yaşında tahta çıkan yeni kraliçe, babasının reddettiği Papalık otoritesine karşı, Reformasyon'un ideallerini paylaşıyordu. Hiçbir zaman deklere etmemiş olsa da, tarihçiler yeni kraliçenin Protestan ideallerine ve İngilizce İncil'e meyletmiş olduğunda hem fikirdir. Gerçekten de uzun süren hükümdarlı̆ında Protestanlık kıta Avrupası'ndan farklı biçimde, bir devlet politikası olarak yaygınlaştı. Yine bu dönemde, dinsel ayrışma "toplumsal harmoni," "refah" ve "istikrar" için tehlike haline gelir. Protestanlık, kişi ve topluluklara kamusal yaşamda ekonomik ve politik manada yani hareket sahaları açar. Yerleşik yapının devamı Katolik inancında sürdürülebilirken, yeni toplumsal aktörler, kendilerine yeni hareket sahalarında özgürce hareket etme olanaklarını sağlayacak yaklaşımlara eğilimlidir. Toplumsal dönüşümün yapısal derinliği ve hızı, yeni olanın etkinliğini arttırmasına yol açar.

$\mathrm{Bu}$ dönem, yenidünyanın keşfinden sonra deniz ticaretinde artan rekabete paralel olarak, kıta Avrupası'nda İspanya'nın politik baskınığına karşı, politik aktörlerin Protestanlığa meylettiği bir süreçtir. İlerleyen süreçte, Hollanda İsyanı (1568-1648) ile doruğa çıan İspanya hegemonyasına karşı başkaldııı, Avrupa politik yapısının yeniden biçimlenmesine neden olmuştur. İspanyol Armadasının İngiltere seferi başarısızlıkla sonuçlandıktan (1588) sonraki süreçte İngiltere'deki çok sayıda Katolik din adamı ihanet ile suçlanarak idam edilmiş ve İngiliz Katolikler giderek toplumsal yaşamın dışına itilerek yabancılaştırımıştır. Bu sayede toplumsal yaşamdan izole edilen eski aktörlerin yerine yeni aktörlerin geldiği bir sürece tanık olunur. On yedinci yüzyılda tüm Avrupa devletleri dinsel problemlerin neden olduğu dahili çatışmalar ile meşguldü. Avrupa devletleri arasındaki ilişkiler devlet yapılarının biçimlenmesini ve dahili problemlerinin çözüm metotlarını etkilemekteydi. Tüm Avrupa devletlerinin istikrar arayışında olduğu politik konjonktürde, İngiltere de toplumsal, politik ve dinsel alanda istikrar elde etmeye çabalamaktaydı (Braddick, 1991: 16). Devlet, bir yandan mezhepler arasındaki çatışmayı olabildiğince ötelemeye çabalarken, diğer yandan toplumsal yapının harmoni ile işleyebilmesi için Protestanlığın egemen olması gerektiğine dair inanç bürokrasi tarafından giderek daha fazla benimsenir. 
Ekonomizmin toplum bilimleri üzerindeki etkisi, modernleşme süreçlerinin endüstri devrimi ve neticelerinden hareketle kavranma çalışılmasına neden olmuştur. Hâlbuki yeryüzünün tamamını etkileyecek kadar özgün değişimlere tekabül eden modernleşme süreçleri sadece ekonomik gelişmelerin etkisi ile ortaya çıkan kalkınma süreçlerine indirgenemez. İngiltere örneğinde de görüldüğü gibi, modern gelişmelerin kökenini oluşturan toplumsal altüst oluşlar devlet sisteminin ve ekonominin yeniden yapılanmasından dinsel ve kültürel dönüşümlere kadar uzanan geniş bir enfrastrüktürde gerçekleşir. Devlet, ekonomi, kültür, din ve toplum birbiri ile etkileşim halinde, yeni gelişmelerin biçimlenişinde çeşitli şekillerde, farklı oranlarda, katkıda bulunmuştur. Bunlar arasındaki eşgüdüm, modern politika, hukuk ve ekonominin tüm yeryüzünde belirleyici olmaya başladığı bir sürecin biçimlenmesini temin etmiştir. Dudley'in düşüncelerinde görünür hale gelen İngiliz devlet ve toplumunun temel yapısını biçimlendiren gayeler "yeni toplum modeli"nin biçimlenmesinde kılavuzluk etmiştir. Ulus devletin, ulusun ve modernliğin üzerinde yükseldiği enfrastrüktür toplumsal aktörlerin refleksif düşünsel etkinliklerinin bir neticesi biçiminde sürekli yapılanmıştır.

\section{Modern İngiltere'nin İlk Döneminde Dini Çeşitlilikteki Artış}

Modern İngiltere'nin ilk dönemindeki toplumsal dönüşümü özellikle VIII. Henry ve I. Elizabeth'in özel hayatları çerçevesinde popüler kaynaklardan da izlemek mümkündür. Bu dönüşümün en önemli göstergelerinden birini de dinsel alanda meydana gelen değişiklikler oluşturmaktadır. Roma Katolik Kilisesinden ayrılarak İngiliz Kilisesini indas eden VIII. Henry dönemi gelişmeleri daha derin politik ve sosyolojik bir arka plana sahip olmasına rağmen genellikle sadece kişisel konforuyla ilgili gelişmeler manzumesi biçiminde ele alınmaktadır. Bu popüler ve yüzeysel yaklaşımın ciddiye alınacak bir tarafı olmamakla birlikte buna karşıt, daha sofistike ancak yine bir o kadar bayağılaştırılmış bir diğer tutum da bütün Reformasyon sürecini ve İngiltere'deki gelişmeleri yalınkat bir sınıfsal gelişime indirgemek biçiminde tezahür eder. Bu yaklaşım uyarınca burjuvazinin ortaya çıkışı bütün bu gelişmelerin arka planını oluşturmaktadır. Bu meyanda İngiliz aydınlanması, Anglikan kilisesinin indası, "İngiliz İç Savaşı" gibi belirleyici olaylar yükselişte olan burjuvazinin Aristokrasi ile savaşımının birer basit göstergesidir. Bu bayağı tutum, söz konusu gelişmelerin özgün arka planını araştırmayı güçleştirmektedir.

İngiltere'de Protestanlığın gelişimi tabii ki Reformasyon'a önemli katkılar yapan Hollanda ile ilişkilerin ticaret yoluyla gelişmesinden ciddi biçimde etkilenmiştir. Hollanda ile ilişkilerin gelişmesi, İngiltere Krallığını Protestan din önderlerine ve Protestan propagandasına açık hale 
getirmiştir. Ancak Katolik kilisesinin müesses nizamı ve Katolik Aristokrasinin engellemeleri bu süreci sekteye uğratmıştır. Bütün bu engellemelere rağmen Güneydoğu İngiltere'de Protestan inancının tutunabildiği yerler olmuştur. Buna rağmen VIII. Henry'nin dönüştürücü girişimi söz konusu olduğunda halk nezdinde Protestanlık hâkim din konumunda değildir. Buna rağmen VIII. Henry'nin bağımsız bir İngiliz Kilisesi indas etmesi ve Katolik Kilisesinden aforoz edilmesi sadece sınıfsal gelişmelerle açıklanamaz. Bu gelişmenin temelinde tabii ki sınıfsal gelişmeler de vardır ancak İngiliz burjuvazisinin Aristokrasi ile iç içe geliştiği gerçeği unutulmamalıır. Bu durumda VIII. Henry'nin bu yönelimini destekleyen burjuvalar ve aristokratlar olduğu gibi karşı çıkan burjuva ve aristokratlar da mevcuttur. Bu nedenle VIII. Henry ile başlayan ve daha sonra "İngiliz İç Savaşı"na kadar geçen dönemdeki toplumsal ve politik gelişmeleri, özellikle de bu dönemde ortaya çıkan çeşitli farklı dinsel yönelimleri anlamak ve açıklamak için sınıfsal tez tek başına yetersiz kalmaktadır. Söz konusu edilen gelişmelerde merkantilist çıkarlar, uluslararası politika (Katolik İspanya'nın dünya hâkimiyetine karşıt olmak, modern bir kavram olarak kralın kendini sınırlayan geleneklerden sıyrıma isteği), gibi sofistike ve karmaşık nedenlerin karşılıklı olarak birbirine etki ettiği dinamik bir süreç söz konusudur. Bu dönemde yaşanan yün ve yünlü kumaş üretiminin tetiklediği toprak çevirme eğiliminin artışı, kumaş ticaretine bağlı olarak ticari burjuvazinin gelişimi, bu gelişime paralel gerçekleşen nüfus hareketleri, ticari ve endüstriyel merkezlerin oluşumu gibi alt üst oluşlar, toplumsal yaşamda özellikle değerler üzerinde bir takım değişiklikler biçiminde görünür olmuştur. Bu değişikliklerin karmaşık etkilerinin en belirgin biçimde izlenebileceği alan dinsel inançlardır. Zira bu dönemde feodal dönemin en belirgin özelliği olan Katolik inancına rakip birçok yeni dinsel eğilim ortaya çıkmıştır.

Modern İngiltere'nin ilk döneminde meydana gelen gelişmelerin yaşam kültürü üzerinde yarattığı büyük değişim dinsel yönelimlerde de açıkça görülür. Bu dönemde tamamı Protestanlığın çeşitli varyasyonlarından oluşan Puritanizm, Presbiteryenizm, Quakerizm, Arminianizm, Waldensianizm, Anabaptizm, gibi (sonraki dönemlerde yenidünya ve Avrupa'daki Protestanlığın çeşitli görünümlerini oluşturacak olan) yönelimler ortaya çıkmışıı. Tamamı dinsel yönelimler olmalarına rağmen Katolik kilisesinin etkinliğini sürdürdüğü ve devlet dini olduğu bu dönem başlangııında, aynı zamanda politik yan anlamlar ve imalar da içermekteydiler. Öncelikle belirtmek gerekir ki, söz konusu edilen tüm dinsel yönelimlerin ortak oldukları nokta Tanrının inayetine ulaşmada "aracı" kabul etmemeleridir. Bu niteliğe eşlik eden diğer motifler Katolik 
inancında önemli bir yer tutan azizler ve onlarla ilgili kutsallık atfedilen emanetlere tazim ve kilisenin ayinsel ve bürokratik yapısıdır. Reformistler bir yandan Katolik kilisesi ve inancının "akla aykırı" ve büyüsel olduğu için paganizm olarak nitelendirdikleri özelliklerini (popery) eleştirirken, diğer yandan kendi aralarında inayete nasıl ulaşılacağı hakkında uzlaşamamaktaydılar. İngiltere örneğinde I. Elizabeth döneminde güçlenen akım olarak Püritenizm, adından da anlaşılabileceği gibi dini inançlarda ve uygulamalarda sadelikten yana idi ve Katolik kilisenin şatafatı ve ağdalı ayinselliğini eleştirip onu pagan olmakla suçlamaktaydı. Bu tutum, modern İngiltere'nin ilk döneminde gelişen ve yukarıda sıralanan tüm yönelimlerde ortak olmakla birlikte mevcut kurulu dinsel düzene muhalif ve dolayısıyla da politik anlamda bir güç dengesine oturdukları için çeşitli görüş ayrılıkları da ortaya çıkmıştır. Yaşanan toplumsal alt üst oluşların bir ifadesi olarak da ele alınabilecek olan bu gelişmeler sonucunda birçok farklı inanç biçimi ve dolayısıyla yeni gruplar sökün etmiştir. Söz konusu bu gruplaşmalar Kıta Avrupa'sında çok derin anlaşmazlıklara ve çatışmalara dönüşerek din savaşları adıyla anılan kanlı çatışmalar biçiminde seyretmiştir. İngiltere'de ise bu çatışmalar uzun süre örtük bir biçimde sürmüş ve kralık makamı yani iktidar üzerinde yoğunlaşarak uzunca bir süre Protestan ve Katolik hanedan üyeleri etrafında oluşan, yerel ve uluslararası taraftarlar arasında seyreden ve çeşitli entrika ve komplolar eşliğinde uzunca bir süre devam eden güç savaşımına dönüşmüştür. Çeşitli farklı inanç biçimlerinin ortaya çıkışı beraberinde örtük çatışmalar ve düzen sağlama girişimlerini de tetiklemiştir. Bu dönem Avrupa'sında ve hatta Amerika'daki kolonilerde olduğu gibi İngiltere'de de politik gerilim ve dinsel farklılaşma sapkınlar ve cadılık iddiasıyla suçlanan insanların yargılandığı veya yakılarak linç edildiği olayların artışına neden olmuştur (Atherton ve Como, 2005).

Politik ve dinsel karmaşanın yarattığı toplumsal huzursuzluk durumlarında kelimenin tam anlamıyla bu türden cadı avı kavrayışının ortaya çıkması moral ve toplumsal düzenin dönüşüm geçirdiğinin göstergelerindendir. Bu ayinsel cezalandırma biçimlerinin temel işlevi topluma üzerinde ittifak edeceği kurbanlar sunmak, bu sayede de bir kohezyon yaratmaktır. Söz konusu sapkınlık ve cadılık iddiaları hoşnut olunmayan inanç ve düşüncelerin ortadan kaldırılması açısından da politik bir amaca hizmet edebilmektedir (Wilby, 2000; Gasky, 2008).

Modern İngiltere'nin ilk dönemindeki durum da bu şekilde tasvir edilebilir. Söz konusu durum öyle bir niteliğe bürünmüştür ki Reformcu inançlar bile kendi aralarında çeşitli anlaşmazlıklara düşmüşler ve bu anlaşmazlıklar Anglikan kilisesinin Katoliklik ve Protestanlık arasında orta yol olarak tesis edilmesi ve güçlendirilmesine kadar giderilememiştir. 
Katolikliğin dini otoriteyi ruhbanla sınırlandıran yapısı karşısında Presbiteryen bir idareden yana olan Püritenler, I. Elizabeth dönemi düzenlemeleri ile Anglikan Kilisesinin episkopal yapısına karşı çıkmışlar ve İngiliz Kilisesinden ayrı düşmüşlerdir (Davies, 1934). Katolik inancındaki pagan unsurlar hakkında görüş birliğinde olan Protestan mezhepleri, Tanrısal inayete erişmede Kilise yerine ikame ettikleri mekanizmalar nedeniyle birbirinden ayrılmaktadırlar. Örneğin Anabaptistlerin Katolik inancındaki vaftiz edilme uygulamasına itirazının altında kişinin Hıristiyanlık inancını bilinçli ve iradi olarak seçmesi gerektiği düşüncesi yatmaktadır. Bu nedenle adlarından da anlaşılabileceği gibi yeniden vaftiz olmak gerektiğini iddia etmişlerdir (Zuck, 1957). Anabaptistler Luther'in insanın günah işleme iradesini ortaya koyduğunu ama bunun yanında iyi işler yapma yükümlülüğünü vurgulamadığını ifade etmişlerdir. Hatta bu kapsamda Luther'in Papanın testisini kırdığını ancak kırıkları elinde tutmaya devam ettiğini ifade eden yazarlar da çıkmıştır (Hillerbrand, 1960). Bu kapsamda onlar daha sonra İngiltere ve Kuzey Amerika'da birçok farklı fraksiyona (Mennonitelar, Hutteritelar, Amishler) kaynaklık edecek olan bir yaklaşımla İncil Hıristiyanlığını yeniden diriltme amacı gütmeye başladıklarını ifade etmişlerdir. Temel nitelikleri dikey bir hiyerarşiyi reddetmeleri ve bireysel kurtuluşu temel alan komüniteryen ve hatta komünist nitelikli eşitlikçi bir yapıya sahip olmalarıdır. Bu yaklaşımları da radikal reformcu şeklinde anılmalarına neden olmuş ve on altıncı yüzyılda İngiltere'de çok ciddi kovuşturmalara uğramışlardır. Bu nedenle daha ziyade sürgünde gelişmişler ve daha önce de belirtildiği gibi Kuzey Amerika'daki kolonilerde varılıklarını sürdürebilmişlerdir. Diğer Protestan fraksiyonlar arasında kurtuluş, inayete nail olmak ve İsa'nın ve Kutsal Ruhun bu kurtuluştaki rolü hakkında da çeşitli görüş ayrılıkları söz konusudur.

Benzer şekilde Quakerizm de on yedinci yüzyıl başlangıçlarında yine reformcu taleplerle ortaya çıkmış ve ruhban karşıtlığında temellenen bir yapı ortaya koymuştur. Quakerlar da diğer reformcu yönelimler gibi İngiliz Kilisesinden, episkopal yapısından dolayı ayrılan yatay düzlemde örgütlenmiş dinsel olduğu kadar toplumsal bir gruptur (Kent, 1982). İngiltere'de Anglikan Kilisesi temellerini sağlamlaştırıp resmi din olunca takibata uğrama tehdidi altında olduklarından, yenidünyaya göç eden Quakerlar, daha sonraki dönemde kendi adlarıla var olan bir cemaat yanında Kuzey Amerika'da ortaya çıkan çeşitli yeni gruplaşmalara da kaynaklık etmiştir. Tarihsel süreçte Kuzey Amerika'da ortaya çıkan bu alt gruplar arasında Hicksitelar, Beaconitelar, Gurneyitelar, Shakerlar ve Evanjelikler sayılabilir. 
Görüldüğü gibi Modern İngiltere'nin ilk döneminde meydana gelen toplumsal gelişmelerin direkt sonucu olarak gelişen ve kimi zaman radikal unsurlara dönüşen dinsel gruplaşmalar ve ayrılıklar günümüz seküler Batı, özellikle de Anglo-Amerikan toplumsal dokusunun, yerel demokrasi anlayışının, sanayileşme ve toplumsal işbölümünün anlaşılabilmesi için gereklidir. İngiltere, kolektif belleği oluşturan değerlerin önemli bir temsilcisi olan dinin, maddi unsurlar yanında ve bazen onların da önünde bireycilik, insan hakları, girişimcilik ve kapitalizm gibi Batılı değerler üzerindeki etkisini ortaya koymak açısından modernitenin en erken görünümünü sunar. İngiltere, modernliğin ekonomik bileşenlerinin yanı sıra dinsel ve kültürel temel yapı taşlarının meydana gelmesinde rol oynayan başlıca faktörlerin, oluşumuna öncülük etmiştir. Hıristiyanlığın farklı yorumlarının çeşitliliğindeki artış, toplumsal dinamizmin bir sunucu olarak ortaya çıkan yeni aktörlerin hareket sahasını genişletmiştir.

\section{Yeni Toplum Modelinin Kuruluş Süreci ve Değişim}

Modern İngiltere'nin ilk dönemi ulusal ve uluslararası sahada yaşanan gerek politik ve ekonomik gelişmelerin birbirlerini etkiledikleri bir süreçtir. İngiliz toplumunun biçimlenmesinde kendi iç dinamikleri kadar, idari mekanizmanın uluslararası gelişmelerin zorlamasıyla aldığı kararlar da etkili olmuştur. Dış ticaretin gelişmesi, toplumun refahını arttırırken, kalkınmayı sürekli hale getirebilmek için okyanuslarda ve uluslararası ticarette etkili olmanın önemi, daha fazla anlaşılmıştır. Modern politika ve ekonominin alt yapısının oluştuğu bu süreçte, yeni bir toplum modeli olarak biçimlenen "ulus"un kültürel dayanakları ve kimliği inşa edilmiştir. Kralığın egemenliği altında entegre olmamış parçalardan ve yerelliklerden oluşan bir "toplum" modelinden "ulus"a geçiş, edebiyat, kültür, hukuk, ekonomi, din, politika ve aile gibi, toplumu oluşturan tüm faktörlerin sürekli yeniden yapılandııımasına yol açarak, "değişimin sürekliliğinin kaçınılmazlığı"na dair bilincin, "ortak bilinç" (collective consciousness) tarafından paylaşılmasına neden olmuştur.

Modern ulusun en önemli niteliklerinden biri, hukuki uygulamalara dair ortak bir bilince sahip olunmasıdır. Modern İngiltere'nin ilk döneminde hukuki uygulamalara dair ortak bilincin kademeli bir biçimde oluşmaya başladığı görülür. Muldrew (1996: 915), 1550 ila 1640 yılları arasında mahkemelere intikal eden hukuki intilaflarda dikkat çekici bir artış olduğunu tespit eder. On altıncı yüzyılın ortasından on yedinci yüzyılın ortasına kadar geçen süreçte hukuki ihtilaflar en yüksek seviyede seyreder. Bu durum toplumsal hareketliliğin ve farkı yerelliklerden gelmiş kişilerin uyumlu davranmalarını temin edecek ortak kültür, gelenek ve kimliğin, henüz tam olarak gerçekleştirilememiş olmasıdır. Devlet eğitim, hukuk ve kültür 
etkinliklerini merkezi düzenlemeler ile tesis etmeye başladıkça, kişilerin birbirleriyle daha uyumlu yaşamalarını temin edecek bir alt yapı oluşmaya başlamıştır.

On altıncı yüzyılın ilk yarısı Tudor hanedanının devleti, toplumu ve ekonomik alt yapıyı yeniden yapılandırmaya başladığı bir dönemdir. İngiliz toplumu ve ekonomisi geri döndürülemeyecek bir biçimde hızlı bir kalkınma sürecine girmişti. İngiltere'deki değişim, toplumu ve devleti oluşturan tüm unsurların yoğun etkileşiminin bir sonucu olarak biçimlenmekteydi. Eski düzende ayrıcalıklı konumda bulunup, yeni sürece ayak uyduramayanların politik dirençleri çeşitli tarzlarda vuku bulmaktaydı. Hızlı değişimin bir sonucu olarak sınıfların ve iktidar mekanizmalarının yeniden konumlanması, çatışmalara neden olmaktaydı. Böylesi bir ortamda, tahta çıkan I. Elizabeth ile birlikte, on altıncı yüzyılın ikinci yarısında, değişim süreçleri ile toplum ve devletin eşgüdümlü hale gelmeye başladığı bir sürece tanıklık edilir. Tudor hanedanı, iktidarının ve otoritesinin meşruluk problemini önemli oranda çözmüştü. Fransa ve İspanya ile uluslararası sahada gerek ekonomik, gerekse politik açıdan rekabetin kaçınılmazlığı ve çatışma ihtimalinin her geçen gün artması, I. Elizabeth'in İngiliz toplumu, ekonomisi ve idari yapısını yeniden biçimlendirme sürecinde, başa çıkmak zorunda kaldığı başlıca problemdi. Devletler arasındaki rekabetin ve çatışma intimalinin artması Papalı̆ın Avrupa politikasındaki gücünü sarsmaktaydı. Uluslararası sahada yeni ticari zenginliklerin nasıl paylaşılacağına dair problemin neden olduğu gergin durum, İngiliz idari yapısının yeni gelişmelere göre yeniden yapılandırılmasını gerektiriyordu. Bu nedenle I. Elizabeth'in ilk yıllarında, William Cecil'in (1520-1598) etkili olduğu "danışma meclisi"nin idari mekanizmadaki etkinliği giderek artar. Ayrıca krallığın iktidarının, başta lortlar olmak üzere, diğer toplum kesimlerinin harmoni ile işlemesini sağlayacak bir parlamentoya dayanmasının, idari mekanizmanın nitelikli işleyişi açısından zaruret arz ettiğine dair kavrayış, giderek güçlenir. Kraliçe, lortlar ve halkın parlamentodaki birlikteliği ve eşgüdümünün, toplumsal düzen, harmoni ve istikrar açısından hayati önem arz ettiği, genel kabul görmeye başlar. Ekonomik kalkınmanın yeni toplumsal aktörlerin etkili olmasına neden olduğu bir toplumda, politik sistemin sadece eski aktörler ile sürdürülebilmesi mümkün değildir. Yeni aktörlerin politik sistemin işleyişine bir biçimde dahil edilmesi gerekir. İngiliz idari yapısı, toplumsal değişimin hızına uyum sağlayabilmek için, yeni faktörleri dikkate alarak, politikaya yani aktörlerin katılımını sağlayacak esnekliği, parlamento sayesinde elde etmeye başlar.

I. Elizabeth'in ilk döneminde, Fransa ile "Avrupa'daki İngiliz toprakları" ve "İskoçya'daki Fransız etkinlikleri" dolayısıyla yaşanan 
gerginlikler nedeniyle, İngiliz idari mekanizmasının asıl problemini uluslararası gelişmeler oluşturduğundan, devletin eşgüdümlü yönetimi, tüm politik aktörler tarafından arzu edilir. İngiltere, bu dönemde (a) idari sistemini daha nitelikli bir yapıya kavuşturmak, (b) sınıfsal ve dinsel kökenli toplumsal çatışmaları ertelemek ve (c) ekonomik kalkınmanın kesintiye uğramasını engellemek için, korumacı bir iç ve dış politika izler. Nihai bir çatışmaya girmekten kaçınmak, İngiliz dış politikasının ana eksenini oluşturur. Bu süreçte, Fransa ile İngiltere arasındaki gerginliği dikkate alan İspanya, kuzeyde egemenlik edinebileceğini öngördü. Burada, uluslararası gelişmelerin idari mekanizmanın yanı sıra toplumsal yapıyı da etkilemesi dikkat çekici bir olgudur. İspanya'nın Avrupa politikasındaki egemenliğini arttırması, İngiltere'nin bağımsız politika sürdürerek ekonomik kalkınmasını devam ettirmek için dinsel bağımsızlığını kazanmaya çalışmasına ve Protestanlığın hızla yayılmasına neden oldu. Protestanlığın dinsel sahada belirleyici olması, uzun çatışmalar yaşandıktan sonra I. Elizabeth döneminin ortalarında galibiyet elde etmesiyle başladı (McClendon, 1999: 2). Bu sayede, İngiltere Kilisesi'nin kurumsal yapısının ve teolojik öğretilerinin dönüşümü, yeni aktörlerin hareket sahasını genişletti. İngiltere kraliçesi ve bürokrasisi, uluslararası sahada başarılı olabilmek için iç çatışmalardan uzak kalmaya gayret gösterdikçe, politik sisteme yeni aktörlerin dahil olmasına daha fazla çaba gösterdi. Politik sisteme parlamento vasıtasıyla dahil edilen yeni aktörler sayesinde idari işleyişin daha etkin olması için eşgüdümlülüğü temin etmek, tüm politik aktörlerin başlıca kaygısı haline geldi. Bu durum, "İngiltere'nin sınıflı bir toplum olmasına" ve "değişimin refah dengelerini değiştirmesine" rağmen, politik sistemin merkezinde yer alan aktörler için (uluslararası gelişmelerden dolayı) birlikteliği temin etmenin başıca gaye haline gelmesine neden oldu.

İngiltere gibi sınıflı bir toplumda çatışmaların tam manasıyla ortadan kaldırıması, özellikle politik ve ekonomik değişimin süreklilik arz ettiği bir durumda, kolay değildir. Politik ve ekonomik güç dengelerinin sürekli yeniden yapılandırıldı̆ı bir süreçte, toplumsal yapıda istikrarı devam ettirmek güçtür. Geçmişte toplumsal yapının aktörlerinin konum ve işlevlerinin daimi olduğu bir toplumsal yapıda geleneksel bir biçimde yaşamlarını sürdüren kişi ve topluluklar, yeni durumlar karşısında kendi çözüm yöntemlerini geliştirmek zorunda kalırlar. Modern yaşamın kompleks nitelikleri, sürekli değişimin yaşamın parçaları arasında çeşitli uyumsuzluklara neden olmasından kaynaklanır. Tüm toplumsal altüst oluşlar karşısında belirli bir istikrar edinme çabası tüm toplumsal aktörlerin başlıca gayesiyken, bir yandan da sürekli dönüşüme ayak uydurmak zorunda kalırlar. 
Modern İngiltere'nin ilk döneminde değişimin dikkat çekici bir şekilde gerçekleştiği başlıca sahalardan biri eğitimdir. Ortaçağ boyunda İngiliz toplumu eğitimsizdi. Eğitim kurumsal nitelik arz etmiyordu. Eğitim okulların yanı sıra hane ve kilise tarafından gerçekleştirilmekteydi. On altıncı yüzyılla birlikte eğitim sahasında da, diğer pek çok sahada olduğu gibi değişim yaşanmaya başalar. Yüzyılın sonuna gelindiğinde değişim çok hızlanmıştır. On sekizinci yüzylın sonuyla birlikte insanlar kendilerini geliştirmek için eğitim kurumlarından faydalanmaya can atıyorlardı. Bunda kültürel etkenler önemli rol oynar. Rönesans'ın etkileri on altıncı yüzyıl İngilteresinde de hissedilmeye başlanır. Hümanizm toplumsal elitlerin dünya görüşlerini ve yaşam tarzlarını etkiler. "Öz-gelişim" elitlerin başıca ideali haline gelir. "Özgelişim"i gerçekleştirebilmek için Yunanca ve Latince öğrenmek, toplumsal elitler arasında giderek popülerleşir. Felsefe, tarih ve edebiyat çalışmalarındaki artış antik eserleri okuyabilen kişi sayısındaki artışa paralel olarak yaygınlaşır. Eğitimli olmanın toplumsal statü ediniminin başlıca unsurlarından biri haline gelmesi, kişilerin "öz-gelişim"lerini olabildiğince ilerletmek için, rekabet etmelerine neden olur. Ayrıca Protestanlığın "dini metin"e (scripture) büyük bir önem atfetmesi ve öğretimini başlıca amaç haline getirmesi, din adamlarının eğitimini de gerektirdi. Tüm bunlar kültürün, eğitim sisteminin ve toplumsal yapının dönüşümüne yol açtı. Aristokratların "hane"leri birer kültür merkezine dönüşerek, mantık, matematik ve astronominin yanında Yunanca ve Latincenin de öğretildiği mekânlar haline geldi. Dönüşüm süreçlerinin eğitim sisteminin kurumsal olarak yeniden yapılanmasını kapsaması zaman aldı. Üniversiteler uzun zaman sadece din adamlarının yetiştirildiği kurumlar olarak algılandı. Ancak üniversitelerin kalıpları, eğitime yönelik ilginin artışı karşısında geri kaldı. Öğrenci sayısındaki hızlı artış, eğitim kurumlarında her alandaki hareketliliği arttırdı. "Öz-gelişim" ideali dinsel eğitimin dışında yeni ilgi sahalarının oluşmasına imkân sağladı. Antik dünyanın "pagan" yazarlarının popülerliği artarken, felsefi, tarihsel, mantıksal ve kültürel problemler gündelik tartışmaların konularını teşkil etmeye başladı. Toplumsal elitlerin eğitime olan ilgilerindeki artış eğitim kurumlarının dönüşümüne neden oldu. Yeni eğitim taleplerini karşılama çabasındaki eğitim kurumları her alanda donanımlı eğitimli kişilerin topluma katıımını temin ederek, toplumsal yaşamın dönüşümüne katkı sundu. Modern gelişmelere ayak uydurmakta zorluk çekmeyecek ve dünyayı farklı tarzlarda yorumlayarak yeni olanakların ortaya çıkmasını sağlayacak donanıma sahip kişi sayısındaki artışın, toplumsal dönüşüm süreçlerinin hızlanmasına neden olması kaçınılmazdı. 
Eğitimin birinci öncelik haline gelmesi, gençlerin aile üretiminden koparak kendi gelişimlerine odaklanmalarına neden olur. Gençler, giderek, eğitimli oldukları zaman kendilerine yeterli olabileceklerini deneyimlemeye başladıkça hanelerinin dışında konforlarını arttırmaya çalışırlar. Aile hiyerarşisinde aşağıda yer alan küçük çocukların eğitim vasıtasıyla kendi yaşamlarını inşa etmeye çabalamaları ve toplumsal dönüşümün yarattığı altüst oluşlardan faydalanarak olanaklarını artırmakta başarılar elde etmeleri, deneyimlerinin örnek teşkil etmesine neden oldu. Eğitim, kişinin yerel bağlamlarından koparak, kendisini daha geniş bir zaman ve mekân kurgusunda ifade edebilmesinin olanaklarını sağlar. Böylesi kişilerden oluşan bir toplumda hareketlilik ve dinamizm yaşamın her sahasına yansır. Şüphesiz ki eğitimli kişilerden oluşan dinamik bir toplumda idari mekanizmanın kendisini sürekli yeniden yapılandırması gerekir. Zira on yedinci yüzyıl İngiltere'sinde kişiler, itibarlı ve saygın olmanın başlıca öncelik olduğu yerel topluluklardan bağımsızlaştıkça, politik ilişkiler rasyonelleşerek ilgi ve çıkara dayanmaya başlar (Shephard, 1992: 744).

İngiliz politik sisteminin ana ekseni, I. James'ten itibaren, olgunluk dönemine girer. Modern İngiltere'nin ilk döneminin olgunluk zamanlarına tekabül eden I. James'in egemenliğinde "anayasa" (constitution) modern anlamda işlerlik kazanmaya başlar. Bu dönemde "anayasa" geleneklerin, kurumların ve temel yasaların toplamının mirası olarak, sadece tek bir otoritenin değil, fakat farklı sesler ile diyalogda olan devlet iktidarını, biçimlendirir (Orr, 2004: 433). Her şeyin yolunda olduğuna inanmak için çok fazla neden bulunmaktadır. I. Elizabeth'in uzun süren hükümdarlığından sonra taşların yerine oturduğu düşünülmektedir. Bilge, dindar ve erkek evlat sahibi bir kral olan I. James ile birlikte İngiltere'yi uzun süren bir istikrar döneminin beklediğinden şüphe etmek için herhangi bir gerekçe mevcut değildir. Ancak modern dönüşüm süreçlerinin yıkıcılı̆ı ve politik aktörlere sağladığı yeni hareket sahaları öngörülemeyenin gerçekleşmesine yol açar. Tudor monarşileri ikili niteliklere sahiptir. İktidarın merkeziyetçi niteliğinin hızla belirginleştiği Tudor monarşilerinde, politik katılım ve istişare devlet mekanizmasının işleyişinde öneli rol oynamaya başlar. Kralın mutlak güç sahibi olmasına rağmen, iktidarın pratik uygulamalarının, yasaya dayalı olarak danışma meclisindeki istişare ile işletildiğinde daha verimli neticelere yol açtığı deneyimlendikçe, parlamentonun önemi artmıştır. Tudor hanedanı süresince, parlamentonun, iktidarın işletilmesine katılımı sağlanarak, idari mekanizmanın daha verimli işlemesinin temin edildiği gözlemlenmiştir. Parlamento krala, tüm sınıfların ve yerelliklerin ilgi, çıkar ve yönelimlerini gözlemleme fırsatı sunduğu gibi, muhtemel çatışmaların da öngörülebilmesini sağlıyordu. Bu sayede 
parlamento giderek entegre hale gelen toplum ile krallık arasındaki eşgüdümü sağlayan aracılık işlevini yerine getirmiş oluyordu.

Modern İngiltere'nin ilk döneminde, krallığın ve toplumun ortak çıkar ve ilgilere sahip olmalarının temini toplumsal düzenin sağlanabilmesi açısından hayatiyet arz ediyordu. Ancak ideal bir biçimde uzun süre devam edeceğine inanılan böylesi bir işleyiş mekanizması, on yedinci yüzyılın ortasına gelindiğinde iç savaşın çıkmasına engel olamayarak yıkıldı. Konsensüs ve harmoniyi sağlamakta mutlak başarı göstereceğine inanılan tüm mekanizmalar işlevsizleşmişti. Bu durumun vuku bulmasında I. Charles'ın İngiltere, İskoçya ve İrlanda'yı tek bir krallığa dönüştürmeyi arzulamasıyla, politik aktörlerin parlamentonun tasfiyesi ile sonuçlanacak bir sürece girildiğinden endişeye kapılmaları, önemli rol oynadı. Modern gelişmelerin toplumsal dinamizmi arttırmasına rağmen, politik sistemin bu gelişmeler çerçevesinde kendini yeniden yapılandıramaması iç savaşa kapı aralamıştır.

"İngiliz İç Savaşı" gibi toplumsal vakaları sosyolog ve siyaset bilimcilerin hassasiyet ile incelemesi gerekir. Zira iktidar dengelerindeki dönüşümün ekonomik ve kültürel boyutlarının analiz edilerek, insanların kriz durumlarında ne tür tutum ve davranışlar sergilediklerinin yapısal analizi için, "İngiliz İç Savaşı" gibi vakalar önemli veriler sağlar. "Toplumsal dengelerin geçmiş uygulamalar ile sürdürülememesi" ve "iktidarın, yeniden yapılanmayı zorlayan toplumsal dönüşüme karşı koymaya çalışması" "İngiliz İç Savaşı"nın vuku bulmasına yol açan başlıca iki etkendir. Parlamento ile kral arasında 1642'de başlayan savaş, Cromwell'in modern gelişme ve gereklilikler dikkate alınarak teşkilatlandırılmış ordusu karşısında I. Charles'ın yenilgiye uğrayarak 1649 'da idam edilmesiyle neticelenmiştir. I. Charles'ın oğlu II. Charles'ın da "Worcester Savaşı"nda yenilgiye uğratılmasıyla iç savaş Parlamento'nun zaferi ile son bulmuştur. "İngiliz İç Savaşı" o zamana kadar insanların deneyimlemedikleri gelişmelerin vuku bulmasına ve tüm İngiliz politik kültürü, toplum yapısı ve dünya görüşünün geri döndürülemeyecek bir biçimde yeniden yapılandırılmasına neden oldu. Bu gelişmelerden en önemlisi, şüphesiz ki II. Charles'ın idamıdır. Daha önce pek çok kral savaş meydanlarında öldürülmüş ya da suikasta uğramıştı. Ama ilk defa bir kral mahkeme tarafından sorgulandı, duruşması görüldü ve idam edildi. Bu olay İngilizlerin politik sisteme dair kavrayışlarını derinden etkileyecektir. İdam sadece bir kişinin öldürülmesiyle sınırlı bir vaka değildir, aynı zamanda kurumsal etkileri de bulunmaktadır. "Kamusal alan"ın toplumun ve politik sistemin işleyişinde önemli bir rol oynamaya başlaması "İngiliz İç Savaşı"ndan sonra kademeli bir biçimde gerçekleşmiştir. Lake ve Pincus (2006) "İngiliz İç Savaşı"ından sonra 
"kamusal alan"ın tüm toplumsal problemlerin tartışılıp çözüme kavuşturulmasında, giderek daha fazla önem arz eden bir rol oynamaya başladığını savunur. Reformasyon'dan sonraki dönemde İngiliz politik sistemindeki önemi artan "kamusal alan," İngiliz Devrim'inden sonra giderek tüm Avrupa'daki politik sistemlerde belirleyici faktör olmaya başlamıştır.

"İngiliz İç Savaşı," toplumsal yapının işletilişinde son derece önemli olan krallık kurumunun, tüm meşruluğunu ve iktidarını kaldırıldığı gibi, cumhuriyetçi kalkışmaların tüm krallar için bir risk teşkil etmek suretiyle, gündemde yer almasına neden olmuştur. Bu nedenle, İngiliz devlet sisteminin işleyiş dinamiklerinin geleneksel niteliklerini derinden zedelemiş olan II. Charles'ın idamı toplumsal etkileri tüm zaman ve mekânlara yayılan bir vakadır. İç savaş sırasında sonraki yıllarda toplumsal etkisini sıklıkla hissettirecek kavram "özgürlük"tür (liberty). İktidarının etki sahasını sınırsızca genişletmeye çalışan bir krala karşı her türlü eylemin meşru olduğuna dair bir politik bilincin gelişmesine neden olan "özgürlük" kavramının yaygın kullanımı, devlet ile kişi arasındaki tüm ilişkilerin sınırlarını ve yapısını biçimlendirecektir. Kralın iktidarını güçlendirmesi ile devletin iktidarının güçlenmesi arasında kategorik bir ayrımın yapılmasına neden olan Parlamento yanlılarının söylemi, devlet mekanizmasında rol alan aktörlerin konumlarının yeniden kurgulanmasını gerektirdi. Ayrıca, ilerleyen süreçte, "hak" (right), "adalet" (justice), "pozitif özgürlük" (positive liberty), "negatif özgürlük" (negative liberty), "toplumsal ahlak" (social morality), "ekonomik özgürlükler" (economic liberties) ve "sınırlı devlet" (limited state) gibi modern politikanın temel kavramlarının, devlet ile kişi arasında şekillenen yeni ilişki tarzları çerçevesinde kavranmalarına neden oldu. Ancak, "İngiliz Devrimi" tam aksi bir biçimde, güç sahibi olanın politik karar alma mekanizmasında belirleyici olacağına dair kadim kavrayışın pekişmesine yol açtı. Cromwell'in sadece bir isyancı değil, fakat bir tiran olarak anılması ahlaksızlıkları ve kontrolsüzlüklerinden kaynaklandığından, olumsuz bir imaja sahiptir (Zaller, 1998: 775). Cumhuriyetçilerin uygulamaları, silahın politikada kullanımının meşruluğunu pekiştirirken, hukukun politik aktörlerin yasadışı etkinliklerini cezalandırabilecek biçimde kurumsallaşmadığı koşullarda, çatışmanın kaçınılmaz olduğunun bir kez daha kavranmasını sağladı. Geleneksel politikanın yerine ikame edilmeye başlanan "değişimin gerekliliği ve kaçınılmazlığının kabulüne dayanan modern politika", hem Makyavelist, hem de uzlaşmacı eğilimleri barındırır. Zaman ve mekânın gerekliliklerine göre politik aktörler kimi zaman Makyavelist, kimi zamansa uzlaşmacı tutum sergilerler. Evrensel hukuk ilkelerinin yerleşmediği politik koşullarda, 
geleneğin bağlayıcıllğından kurtulmuş olan politik öznelerin, iktidarlarının etkinlik sahasını en son sınıına kadar zorlama eğiliminde olmaları "kaygı"nın (anxiety) politika sahası üzerindeki belirleyiciliğinden kaynaklanır.

\section{Sonuç}

Modernliğin toplumsal sonuçları, toplum bilimlerinin başlıca temalarından biridir. Tüm dünyadaki toplum yapılarını çeşitli derecelerde etkilemiş olan modernliğin, özellikle on sekizinci yüzyllın sonundan itibaren neden olduğu değişimlerin kapsamı son derece geniştir. Modernliğin tüm toplumlardaki "iletişim" ve "etkileşim"in hızını arttırması, toplulukların yerel nitelikli kapalılık durumlarının sağladığı istikrarları sarsmıştır. Modernliğin aynı mekân ve zamanı paylaşmayan tüm özneleri her alanda etkileşime yöneltmesi, değişimi kaçınılmaz hale getirmektedir. Tümünün tam manası ile belirlenmesi zor olan pek çok faktörün etkisiyle biçimlenen modernliğin temel nitelikleri, tarihteki çeşitli etkileşim süreçlerinin, toplumları değişime zorlamasıyla oluşmuştur. Modern değişim süreçlerinin hızlanmasını sağlayan başıca etken, tüm birey, grup ve sınıfların yoğun bir "iletişim" ve "etkileşim" sürecine girmeleridir. Modern ulusun oluşumu, tüm toplumun, kendisini tanımlayabileceği ve nasıl yaşayacağına dair verileri temin edebileceği, ortak hukuk, kültür ve politikanın, eşgüdümlü toplumsal eylem ile oluşturulmasıyla başlar. Modern İngiltere'nin ilk döneminde, birbirleri arasında karşılıklı bağlantıları zayıf olan yerelliklerin, iletişim ve etkileşimle birbirlerine entegre olmaya başlamalarına tanık olunur. I. Charles'ın son dönemlerinde ve Parlamento'nun yönetimde bulunduğu süreçte, "haber mektupları"nın (newsletters) basımı ve dolaşımındaki artış (Baron, 2005: 53) güçlenen iletişim ağının en belirgin göstergesidir. Modernliğin oluşum sürecinin İngiltere'de on altıncı yüzylın başından itibaren giderek hızlanması ve etki sahasını genişletmesi, tüm toplumsal aktörlerin birbirleri ile çeşitli şekillerde iletişime geçmelerini sağlayacak kurumsal ve ekonomik mekanizmaların ortaya çıkmalarına tanık olunmasından kaynaklanır. Modernliğin insanlar arasındaki ekonomik ve politik etkileşimin farklı mekânlarda bulunanlar arasında gerçekleşmesini sağlaması, modern toplumların dinamik karakterinin başlıca sebebidir. Bu sayede geleneksel istikrar kalıpları yıkılırken, modern toplumun kuruluşunun temel yapı taşları da tesis edilmeye başlar.

İnsanların, farklı mekânlarda yaşayanların ekonomik etkinlikleri hakkında bilgi sahibi olmak için büyük bir istek duymaları, on yedinci yüzyıldaki başlıca gelişmedir. Ekonomik ve politik gelişmeler, mekânı diğer mekânların etkisine açtıkça, insanın varlığını arzu ettiği gibi sürdürüp, yaşamını inşa edebilmesi ile dı̧ dünyadan "haberdar" olmak arasında kuvvetli bağlar oluşmuştur. 1605 ylında Almanya'nın Strasbourg kentinde yayınlanan "Relation aller Fürnemmen und gedenckwürdigen Historien" ile birlikte haberin dolaşımını sağlayan ağlar daha nitelikli bir biçimde tesis edilmeye başlar (Schröder, 2005: 123). On yedinci yüzyılın başından 
itibaren Avrupa'da birbiri ardına çok sayıda matbaanın gazete çıkarmaya başladığına tanık olunur. On yedinci yüzyılın başından itibaren, el yazısıyla hazırlanan "haber mektupları"nın yerini hızla gazeteler alır (Lankhorst, 2005: 154). 1665 yılında yayınlanmaya başlanan "Oxford Gazette"in yaklaşık bir yıl sonsa adını değiştirerek "The London Gazette" olarak yayın hayatına devam etmesiyle, düzensiz haber mektuplarından sistemli bilgi akışını sağlayan haberciliğe doğru önemli bir atılım gerçekleştiren İngiltere, iletişimin topluma önemli bir dinamizm katacağının örneklerini sergilemeye başlar. İngiliz toplumunun "haber merkezli" (news-oriented) bir nitelik kazanmasının "The London Gazette"in yayımlanmasından sonraki yirmi yıllık bir periyodda gerçekleşmiş olması (Woolf, 2005: 97), toplumsal dönüşümün hızının en açık göstergesidir. On yedinci yüzyılda politik enformasyonun gündelik hayatın bir parçası haline gelmesi (Dooley, 2005: 275), "kamusal alan"ın olgunlaşmaya başladığını göstermektedir. "Kamusal alan"ın politik ve ekonomik karar alma mekanizmaları üzerindeki etkisi toplumsal yaşamın yapılanışını ve algılanışını dönüştürerek toplumun "ortak" ulusal kimlik, kültür, hukuk ve politik sistem etrafında, merkeziyetçi bir nitelik arz edecek biçimde yapılanmasına neden olmuştur.

Bir toplumda aile hayatının, aile kurumun toplumsal işlevlerinin, kimliklerin, sınıfların, ekonominin, hukukun, beğenilerin ve politik sistemin hep birlikte dönüşmeye başladığı zaman dilimleri, toplum bilimleri açısından hayati veriler sunar. Özellikle, on altıncı yüzyıldan önce, değişimin son derece yavaş gerçekleşen bir olgu olduğu dikkate alınacak olursa, on altıncı yüzyıldan sonraki kuşaklar için, hayatın ne derece farklılaşmaya başladığı daha net biçimde kavranabilir. Değişimler çeşitli krizlerin ortaya çıkmasına neden olur. Örneğin, "İngiliz İç Savaşı" toplumsal değişimin neticesinde güç dengelerinde ortaya çıkan değişimin kaçınılmaz bir sonucu olarak vuku bulmuştur. Ancak modernlik, kişi, grup ve sınıfların değişime nasıl uyum sağlayacaklarına dair bilinçlenmelerini de temin eder. Değişim, kaygının artmasına neden olarak, toplumsal gerilimlere yol açar. Gelgelelim, değişimin kaçınılmaz olduğu kabul edildikten sonra, değişime uyum sağlayamamak kaygının artmasına neden olur. Değişimin kaçınılmaz olduğu ortak bilinç tarafından kabul edildikten sonra, değişimi toplumsal düzeni bozmadan sürdürebilmenin kültürel, politik ve ekonomik alt yapısı oluşturulmaya çalışılır. Bir yandan toplum birbiriyle etkileşimi güçlenen yerelliklerin harmonisi ile merkeziyetçi bir biçimde yeniden yapılanırken, diğer yandan yerelliklerin politik sisteme katılımını sağlayacak mekanizmaların tesisi ile refahın bölüşümünün modern gerekliliklere göre düzenlemesi, koordineli bir biçimde ilerler. "İngiliz İç Savaşı"ndan sonraki süreçte İngiliz toplumunun yeniden yapılanma süreci, modern toplumların 
dinamik karakterini gözler önüne sermektedir. Cromwell'in ölümünden sonra, tahta geçerek restorasyon dönemini başlatan II. Charles, on sekizinci yüzyılın ilk dönemine kadar hızlanarak devam eden ekonomik gelişmelere öncülük eden bir alt yapının oluşumunu temin etti. İngiltere'nin politik ve ekonomik açıdan gelişimini, tüm yeryüzünü etkileyecek biçimde hızlandırması, toplumsal yapısının da yeniden yapılandırılmasını gerektirmiş̧ir.

İngiliz toplumundaki dönüşümün başlıca (a) aile, (b) din, (c) ekonomi ve (d) politik sistem sahalarında yaşandığı görülmektedir. Bu sahaların her birinde yaşanan dönüşüm diğer sahaları da etkilediğinden, faktörlerin birbirleri ile yoğun etkileşimde olduğu bir süreç yaşanmıştır. Gelgelelim, tüm sahalarda dönüşüm yaşanmasını tetikleyen en önemli faktörlerden biri "iletişim ve etkileşimin yoğunlaşması"dır. (a) Aile kurumunda gözlemlenen dönüşüm, ekonomik ve kültürel gelişmelerin daha fazla kişiye, aile dışında yaşamlarını inşa edebilecekleri sahalar açmasıyla, bireyciliğin yükselen değer haline gelmesinden kaynaklanır. "Öz-gelişim" idealinin yaygınlaşması, kendi yaşamını bağımsız bir biçimde inşa etmek isteyen kişilerin, aile ve yerelliklerinden koparak bireyselleşme arzusuna kapılmalarından dolayıdır. Aile kurumunun üyelerine sağladığı olanaklar giderek azalırken, üretim işlevleri de kademeli olarak, modern kurumlara devredilir. Devlet kişinin kendi yaşamını ailesinden bağımsız bir biçimde inşa edebilmesinin olanaklarını sağlayacak kapitalist gelişmelerin yolunu açar. (b) Toplumsal değişim, sabitelerinden vazgeçmemekte son derece ısrarcı davranan Katoliklik yaşam kalıplarının sürdürülebilirliğini zorlaşıırmıştır. Yerelliğinden bağımsızlaşan bireylerin, gündelik yaşam pratiklerini ve ticari etkinliklerini serbestçe devam ettirebilmeleri için yeni bir dünya görüşüne intiyaç duymaları Hıristiyanlığın yorumlanış tarzlarındaki çeşitliliği arttırmışıı. İngiliz politik sisteminin, uluslararası gelişmelerden dolayı, Papalığa eskiden olduğu gibi bağımlı kalarak işletilebilmesinin olanaksız hale gelmesi, Protestanlığın yaygınlaştııımasının devlet politikasına dönüşmesine yol açtı. Kişi ile Tanrı arasındaki "aracı"ların kaldırıması için tüm güçleriyle çalışan yeni mezhepler, modern kültürün gelişimi için elzem olan bireyin ve bireyci dünya görüşlerinin gelişimini hızlandırdı. (c) Ekonomik gelişmeler toplumun, sınıfsal niteliklerinden kurumsal işleyişine kadar tüm yapısının yeniden biçimlenmesine neden oldu. Nüfus artışılla birlikte daha fazla üretimde bulunmanın bir gereklilik haline gelmesi, toprakların değerini arttıırken, işlenmiş hammaddelerin değerindeki hızlı artış insanları daha fazla üretime sevk etti. Keşifler ile Avrupa'da değerli madenlerin miktarındaki artış enflasyonu artııırken, özellikle İngiltere'de kumaş üretiminin daha nitelikli ve yaygın hale 
gelmesine yol açtı. Tarımsal üretimin yanında, ham maddelerin işlenmesine dayalı üretim olanaklarındaki artış, kişilere toprağa ve yerelliklere bağı kalmadan, yaşamlarına yön verebilme olanağı sağladı. (d) Tüm bu gelişmeler karşısında İngiliz politik sistemi, yeni koşullara uyum sağlayarak iktidarını daha nitelikli bir biçimde işletebilmek amacıyla, kurumsal yapısını revize etti. Bunu yeni toplumsal aktörlerin politik sisteme dahil olmalarını sağlayacak "danışma meclisi" ve "Parlamento" ile gerçekleştirdi. Modern politikanın belirleyici olmaya başlamasıyla geçmiş politik sistem idealleri de zamanla geçerliliğini yitirdi. İdeal bir biçimde kurgulanmış "altın çağ"ın referans alınmasıyla politik sistemin düzenlenmesine dayanan geleneksel politikalar, modernliğin değişimi kaçınılmaz hale getirdiği koşullarda anlamını yitirdi. Zira her şeyin en ideal bir biçimde konumlandırılarak sürdürülmesinin olanağı ortadan kalkmaktaydı. Modernlik koşullarında gerçekleşen değişimlerin dikkate alınması ile kurumların, rollerin ve işlevlerin sürekli revize edilmesini gerektirdiğini kısa sürede idrak eden İngiliz politikasının aktörleri, toplumsal değişime paralel bir biçimde politik sistemi de sürekli revize etmenin yapısal olanaklarını gerek kurumsal, gerekse kültürel manada meydana getirdiler.

İngiliz toplumu, modernlik koşullarında "toplumsal düzen"in değişimin engellenmesiyle temin edilemeyeceğini kültürel manada kavradı. Hem dahili, hem de harici faktör ve aktörlerin sürekli etkileşimde bulundukları koşullarda, öznenin içinde bulunduğu mekandaki koşulların değişmeden sürdürülebilmesi olanaksızlaşır. Diğer mekânlardaki gelişmeler bir biçimde farklı mekânlardaki toplumların kuruluş tarzlarının dönüşmesine neden olur. Bunu sağlayan başlıca iki etken "kapitalizm" ve "iletişim sistemleri"dir. Kapitalizm üretimini arttırmak için yeni hammadde kaynaklarına ve tüketicilere intiyaç duyar. Yeni hammadde ve tüketicilere ulaşabilmesi için, "diğer" mekânların kendi kurallarına göre yapılandırılması gerekir. Ticaretin "evrensel hukuk"un belirlediği kurallar çerçevesinde gerçekleştirilmesi, sürdürülebilirliğinin imkânını arttııır. Bu sayede kapitalizm zamanda ve mekânda hızla yayılarak bir dünya sistemi olarak kuruluşunu sürdürme olanağına kavuşur.

Gelgelelim, toplumsallığın üzerinde durduğu enfrastrüktürün sürekli değiştiği koşullarda, tüm öznelerin konumları ve işlevleri yeniden yapılanırken, çatışma yaşanmadan "toplumsal düzen"in nasıl sürdürülebileceği problemi tüm modern politik sistemin başlıca belirleyicisidir. Değişim ile istikrarı bir arada sürdürebilmek, modern politikanın başa çıkmak zorunda kaldığı en büyük güçlüktür. Hukuk ve ekonomik ilkelerin yanı sıra ahlak ve değer sistemlerinin de her geçen gün zamanın ihtiyaçlarını karşılamakta yetersiz kalmalarıyla birlikte, yerlerine 
yenilerinin ikame edilmesinin zorunlu hale gelmesi "toplumsal düzen"in sürdürülebilirliği problemini içinden çııılması zor bir fasit daireye dönüştürmektedir. Bu durum ile karşılaşan ilk toplumlardan biri İngiliz toplumudur. Modern İngiltere'nin ilk döneminde değişimin kaçınılmazlığı "toplumsal düzen"in hem kurumlar olarak, hem de bireyler bazında sarsılmasına neden olmuştur.

Tüm yerelliklerin değişim karşısında yenilgiye uğrayarak, merkeziyetçi politik, kültürel ve ekonomik uygulamalara uyum sağlamak zorunda kaldığı modernlik koşullarında, geleneksel yaşam kalıplarının sürdürülebilirliğinin olanakları azaldığından, kişiler yaşamlarını geçmiş kuşaklardan devraldıkları veriler ile kurgulayamazlar. İş bölümünün çeşitlenmesine neden olan modern üretim ve tüketim tarzları kişileri, yeni olana uyum sağlamaya zorlar. Bu sayede ortaya çıkan yaşam tarzlarının çeşitliliğindeki artış, dünyanın farkı şekillerde algılanabileceğine ve yaşanabileceğine dair bir bilincin oluşmasına yol açar. Ancak, kişi ile devlet arasındaki aracı kurumların kaldırıması ve bireyciliğin başlıca ideoloji haline gelmesi ile geleneksel toplumsal yapının dayanaklarının sarsılması çok sayıda toplumsal sorun ve olumsuz sonuçları ile başa çıkılmak zorunda kalınmasına neden olur. "İletişim sistemleri"nin kişilerin farklı mekân ve zamanlara dair bilgi edinme olanaklarını arttırması, yerellikleri harici faktörlerin etkilerine açtıkça, değişimin hızı da artar. Var olanı muhafaza etmenin her geçen gün daha da zorlaşmasına neden olan bu durum, değişimin sağladığı olanaklar ile yarattığı kaygılar arasına sıkışan kişilerin, devletin teminatıyla sürdürülen "soyut sistemler"e (abstract systems) giderek daha fazla bağlanmalarına neden olur. Kişilerin yerel bağımlılık ilişkilerinden koparak, "soyut sistemler"e entegre olmaları modern ulusal toplumların kuruluş sürecinin en önemli mihenk taşıdır. Modern İngiltere'nin ilk dönemi, "ekonomi," "politik sistem," "iletişim sistemleri" ve "kültür" arasındaki eşgüdümlülüğün, modernleşme süreçleri açısından ne derece önemli olduğuna dair önemli bir örnektir. Devletin, yerel niteliklerin egemen olduğu bir toplumsal yapıdan, "ulusal kimlik" etrafında bir araya gelmiş yekpare bir modern toplum yapısına geçiş sürecinde, toplumu oluşturan tüm yapı taşlarını koordineli bir biçimde işletme becerisini gerçekleştirmesinin önemi, modern İngiltere'nin ilk dönemi örneğinde sarihçe gözlemlenmektedir.

\section{Kaynakça}

Atherton, Ian \& Como, David. (2005). The Burning of Edward Wightman: Puritanism, Prelacy and the Politics of Heresy in Early Modern England. The English Historical Review, Vol. 120, No. 489, ss. 1215-1250. 
Baron, Sabrina A. (2005). The Guises of Dissemination in Early Seventeenth-Century England News in Manuscript and Print. Brendan Dooley, \& Sabrina A. Baron, (Ed.). The Politics of Information in Early Modern Europe içinde. London \& New York: Routledge Press, ss. 41-56.

Bernstein, Paul. (1997). American Work Values: Their Origin and Development. New York: State University of New York Press.

Braddick, Michael. (1991). State Formation and Social Change in Early Modern England: A Problem Stated and Approaches Suggested. Social History, Vol. 16, No. 1 (Jan., 1991), ss. 1-17.

Brodie, D. M. (1932). Edmund Dudley: Minister of Henry VII. Transactions of the Royal Historical Society, Fourth Series, Vol. 15, ss. 133-161.

Clymer, Lorna. (2008). Religion and Cultural Transformation in Early Modern England: Introduction. Huntington Library Quarterly, Vol. 71, No. 4, ss. 553-555.

Cressy, David. (1986). Kinship and Kin Interaction in Early Modern England. Past \& Present, No. 113, ss. 38-69.

Davies, Godfrey. (1934). Arminian versus Puritan in England, ca. 16201640. The Huntington Library Bulletin, No. 5, ss. 157-179.

Dooley, Brendan. (2005). News and Doubt in Early Modern Culture: Or, Are We Having A Public Sphere Yet? Brendan Dooley, \& Sabrina A. Baron, (Ed.). The Politics of Information in Early Modern Europe içinde. London \& New York: Routledge Press, ss. 275-290.

Dudley, Edmund. (1948 [1509-1510]). The Tree of Commonwealth, (ed. D. M. Brodie). London \& Cambridge: Cambridge University Press.

Erickson, Amy Louise. (1990). Common Law versus Common Practice: The Use of Marriage Settlements in Early Modern England. The Economic History Review, New Series, Vol. 43, No. 1, ss. 21-39.

Everitt, Alan. (1966). Social Mobility in Early Modern England. Past \& Present, No. 33, ss. 56-73.

Fox, Harold S. A. (1988). Social Relations and Ecological Relationships in Agrarian Change: An Example from Medieval and Early Modern England. Geografiska Annaler. Series B, Human Geography, Vol. 70, No. 1, Landscape History, ss. 105-115.

Gaskill, Malcolm. (2008). Witchcraft and Evidence in Early Modern England. Past and Present, No. 198, ss. 33-70.

Harrison, C. J. (1972). The Petition of Edmund Dudley. The English Historical Review, Vol. 87, No. 342, ss. 82-99.

Hillerbrand, Hans J. (1960). Anabaptism and the Reformation: Another Look. Church History, Vol. 29, No. 4, ss. 404-423.

Jones, Whitney R.D. (2000). The Tree of Commonwealth, 1450-1793. London: Associated University Press.

Kent, Stephen A. (1982). Relative Deprivation and Resource Mobilization: A Study of Early Quakerism. The British Journal of Sociology, Vol. 33, No. 4, ss. 529-544. 
Kiser, Edgar \& Kane, Joshua. (2001). Revolution and State Structure: The Bureaucratization of Tax Administration in Early Modern England and France. American Journal of Sociology, Vol. 107, No. 1, ss. 183-223.

Kussmaul, Ann S. (1979). Servants in Husbandry in Early Modern England. The Journal of Economic History, Vol. 39, No. 1, The Tasks of Economic History, ss. 329-331.

Lake, Peter \& Pincus, Steve. (2006). Rethinking the Public Sphere in Early Modern England. Journal of British Studies, Vol. 45, No. 2, ss. 270292.

Lankhorst, Otto. (2005). Newspapers in the Netherlands in the Seventeenth Century. Brendan Dooley, \& Sabrina A. Baron, (Ed.). The Politics of Information in Early Modern Europe içinde. London \& New York: Routledge Press, ss. 151-159.

McClendon, Muriel C. (1999). A Moveable Feast: Saint George's Day Celebrations and Religious Change in Early Modern England. Journal of British Studies, Vol. 38, No. 1, ss. 1-27.

McRae, Andrew. (1993).To Know One's Own: Estate Surveying and the Representation of the Land in Early Modern England. Huntington Library Quarterly, Vol. 56, No. 4, ss. 333-357.

Muldrew, Craig. (1996). The Culture of Reconciliation: Community and the Settlement of Economic Disputes in Early Modern England. The Historical Journal, Vol. 39, No. 4, ss. 915-942.

Murphy, Terence R. (1986). Woful Childe of Parents Rage: Suicide of Children and Adolescents in Early Modern England, 1507-1710. The Sixteenth Century Journal, Vol. 17, No. 3, ss. 259-270.

Nisbet, Robert A. (1948). The Politics of Social Pluralism: Some Reflections on Lamennais. The Journal of Politics, Vol. 10, No. 4 (Nov., 1948), ss. 764-786.

Nisbet, Robert A. (1959). The Decline and Fall of Social Class. The Pacific Sociological Review, Vol. 2, No. 1, ss. 11-17.

Orr, D. Alan. (2004). A Prospectus for a "New" Constitutional History of Early Modern England. Albion: A Quarterly Journal Concerned with British Studies, Vol. 36, No. 3, ss. 430-450.

Pennell, Sara. (1999). Consumption and Consumerism in Early Modern England. The Historical Journal, Vol. 42, No. 2, ss. 549-564.

Postles, Dave. (2004). The Market Place as Space in Early Modern England. Social History, Vol. 29, No. 1, ss. 41-58.

Rollison, David. (2001). Discourse and Class Struggle: The Politics of Industry in Early Modern England. Social History, Vol. 26, No. 2, ss. 166-189.

Rose, Jacqueline. (2011). Kingship and Counsel in Early Modern England. The Historical Journal, 54, 1 (2011), ss. 47-71.

Schröder, Thomas. (2005). The Origins of the German Press. Brendan Dooley, \& Sabrina A. Baron, (Ed.). The Politics of Information in 
Early Modern Europe içinde. London \& New York: Routledge Press, ss. $123-150$.

Sharpe, J. A. (1981). Domestic Homicide in Early Modern England. The Historical Journal, Vol. 24, No. 1, ss. 29-48.

Shepard, Alexandra \& Spicksley, Judith. (2011). Worth, age, and social status in early modern England. Economic History Review, 64, 2, ss. 493-530.

Shephard, Robert. (1992). Court Factions in Early Modern England. The Journal of Modern History, Vol. 64, No. 4, ss. 721-745.

Walker, Garthine. (2008). Crime, Gender and Social Order in Early Modern England. London \& Cambridge: Cambridge University Press.

Wallerstein, Immanuel. (1974). The Modern World-System: Capitalist Agriculture and the Origins of the European World Economy in the Sixteenth Century. New York: Academic Press.

Wallerstein, Immanuel. (1980). The Modern World-System II: Mercantilism and the Consolidation of the European World Economy, 16001750. New York: Academic Press.

Wallerstein, Immanuel. (1989). The Modern World-System III: The Second Era of Great Expansion of the Capitalist World-Economy, 17301840. New York: Academic Press.

Walter, John \& Wrightson, Keith. (1976). Dearth and the Social Order in Early Modern England. Past \& Present, No. 71, ss. 22-42.

Westhauser, Karl E. (1994). Friendship and Family in Early Modern England: The Sociability of Adam Eyre and Samuel Pepys. Journal of Social History, Vol. 27, No. 3, ss. 517-536.

Wilby, Emma. (2000). The Witch's Familiar and the Fairy in Early Modern England and Scotland. Folklore, Vol. 111, No. 2, ss. 283-305.

Woolf, Daniel. (2005). News, History and the Construction of the Present in Early Modern England. Brendan Dooley, \& Sabrina A. Baron, (Ed.). The Politics of Information in Early Modern Europe içinde. London \& New York: Routledge Press, ss. 80-122.

Wrightson, Keith \& Levine, David. (1995). Poverty and Piety in an English Village: Terling 1525-1700. Oxford: Oxford University Press.

Wrightson, Keith. (1982). English Society 1580-1680. New Brunswick, New Jersey: Rurgers University Press.

Wrightson, Keith. (2000). Earthly Necessities: Economic Lives in Early Modern Britain 1470-1750. New Haven, CT: Yale University Press.

Zaller, Robert. (1998). Breaking the Vessels: The Desacralization of Monarchy in Early Modern England. The Sixteenth Century Journal, Vol. 29, No. 3, ss. 757-778.

Zuck, Lowell H. (1957). Anabaptism: Abortive Counter-Revolt within the Reformation. Church History, Vol. 26, No. 3, ss. 211-226. 